\title{
Rumen development in the calf
}

\section{2.* The effect of diets containing different proportions of concentrates to hay on digestive efficiency}

\author{
By I. J. F. STOBO, J. H. B. ROY AND HELEN J. GASTON \\ National Institute for Research in Dairying, Shinfield, Reading
}

(Received 13 April 1965-Accepted 24 November 1965)

\begin{abstract}
I. Twenty-four Ayrshire bull calves were reared on either high-concentrate or high-roughage diets to study the effect of diet on the subsequent ability of the calf to digest either concentrates or hay when given alone. The rearing diets were known to produce different types of rumen development. 2. Although there were significant differences between the apparent digestibility coefficients of the high-concentrate and high-roughage rearing diets and between concentrates and hay when given alone, the subsequent ability of the calf to digest either concentrates or hay was unaffected by the type of diet given during the rearing period to 13 weeks of age. 3. The amount of nitrogen retained was significantly greater in calves reared on the highconcentrate diet than in those given the high-roughage diet, but similar amounts of $\mathrm{N}$ were retained/100 g gain in body-weight in both groups. After the change in diet, the amount of $\mathrm{N}$ retained was significantly greater in calves given concentrates after a rearing diet high in concentrates than in those given concentrates after a rearing diet high in roughage, although in both groups $32 \%$ of the $\mathrm{N}$ intake was retained. Four of the six calves given hay after a rearing diet high in concentrates were in negative $\mathrm{N}$ balance, but only one calf lost weight. Only $19 \%$ of the $\mathrm{N}$ intake was retained in calves given hay after being reared on a highroughage diet. 4. The concentration of total volatile fatty acids (VFA) in the rumen contents rose to reach peak levels at about $3 \mathrm{~h}$ after food was offered; the concentration then declined. VFA concentrations tended to be higher in calves given the rearing diet high in concentrates than in those given the one high in roughage, and differences reached significance when the diet was changed to one of all concentrates or all hay, with no obvious carry-over effect of the rearing diet. The proportion of propionic, butyric and higher acids tended to be greater in calves given high levels of concentrates than in those given high levels of hay and also tended to rise, irrespective of diet, as the concentration of total VFA rose. 5. A change of diet at I4 weeks from one high in concentrates to one consisting entirely of hay resulted in a significant decline in the viable counts of streptococci, lactobacilli and coliform organisms in the rumen liquor at I6 weeks. The numbers of bacteria were unaffected by the other dietary changes. 6 . The concentration of total VFA in plasma of peripheral blood tended to be higher in calves given the high-roughage or all-hay diets. A fall in the concentration of plasma VFA occurred when calves were changed from a high-roughage diet to an all-concentrate diet and a rise in concentration was observed when an all-hay diet replaced one containing a high proportion of concentrates. 7. During the initial rearing period the mean blood plasma glucose concentration was $92.8 \mathrm{mg} / 100 \mathrm{ml}$ in calves given the high-concentrate diet, a value significantly higher than the mean value of $64.5 \mathrm{mg} / 100 \mathrm{ml}$ found in calves given the high-roughage diet. The concentration of plasma glucose rose to $89.8 \mathrm{mg} / 100 \mathrm{ml}$ in calves changed from the high-roughage diet to concentrates and declined to $8 \mathrm{I} .7 \mathrm{mg} / \mathrm{ro0} \mathrm{\textrm {ml }}$ in calves that were given hay in place of the high-concentrate diet. 8 . The weight of contents of the reticulo-rumen and omasum and the volume displacement of these organs were significantly greater in calves given hay as the sole diet during the last 3 weeks of life than in those given concentrates during this period. The weight of tissue forming the reticulo-rumen was significantly greater in calves given the allconcentrate diet during the last 3 weeks of life than in those given only hay during this period. It was apparent that the rumen papillas developed rapidly in those calves given concentrates as the sole diet for a period of 3 weeks after a rearing diet high in roughage, whereas there was a marked retrogression of papillas when concentrates were withdrawn from the diet. 9. It is concluded that the ruminant calf adapts readily to marked dietary changes, with the result that differences in the size and structure of the ruminant stomach, which have been shown to occur when different types of diet are given, have no permanent effect on the ability of the calf to digest diets of concentrates or hay.
\end{abstract}

* Paper no. I : Br. F. Nutr. (1966), 20, I71. 
The view has been widely held by farmers and advisory workers that, in order to be able to utilize efficiently diets containing a fairly high proportion of roughage, cattle must receive a liberal supply of roughage during the rearing period. Although several workers (e.g. Filmer, 1952; Crichton \& Aitken, 1954; Reid, Loosli, Turk, Asdell \& Smith, 1957) have studied the effect of different planes of nutrition during the rearing period on such factors as age at calving, milk yield and longevity, they did not examine the effect on digestive efficiency. Hansson, Brännäng \& Claesson (I953), in an experiment using monozygous twins, found that, although the most efficient utilization of food for growth occurred in heifers reared on a low plane of nutrition from I month of age, there was no difference in digestive efficiency between animals on different planes of nutrition at 2 years of age. However, since the diet for both high and low planes of nutrition consisted of the same mixture of concentrates and chopped roughage given at two different levels, the effect of diets high or low in roughage on subsequent ability to utilize foodstuffs was not examined in the investigation.

The effect of giving diets of either high or low roughage content to monozygous twin heifers during the rearing period from 4 months to 2 years of age was studied at this Institute by Balch, Campling, Johnson \& Roy (1960). They found that the method of rearing had no effect on the subsequent ability to digest hay or mixed rations of hay and concentrates, but were unable to examine the anatomy of the rumen.

In a recent experiment Stobo, Roy \& Gaston (1966) found that, in calves weaned at 5 weeks of age, diets containing a high proportion of concentrates stimulated rapid weight gains and marked development of the mucosal layer of the reticulo-rumen, whereas diets consisting mainly of hay resulted in poorer growth and increased the capacity of the reticulo-rumen without causing extensive papillary development. A similar association, between large weight gains and advanced stages of rumen papillary development, has been reported in the young lamb (Sinclair \& Künkel, 1959). It seemed pertinent, therefore, to examine the relationship between rumen development and digestive efficiency in the early-weaned calf.

In the previous experiment (Stobo et al. 1966), the two extreme types of rumen development were obtained in calves given concentrates to a maximum of $2 \cdot 27 \mathrm{~kg} /$ day or $0.45 \mathrm{~kg} / \mathrm{day}$; the proportions of concentrates to hay at $\mathbf{2} 2$ weeks of age were 9: $\mathrm{I}$ and $\mathrm{I}: 3$ respectively. The same two basic treatments were used in the experiment reported here, first, to investigate the ability of the early-weaned calf to digest diets of concentrates and hay in proportions known to produce different types of rumen development, and secondly, to study the effect of diet during the rearing period to I2 weeks of age on the subsequent ability of calves to digest either concentrates or hay.

\section{METHODS}

Plan of experiment

The experiment was made between September I959 and June I96I, using twentyfour Ayrshire bull calves from 3 weeks of age, in a randomized block design consisting of six blocks, each containing four treatments. The composition of the concentrate mixture and management of the calves during the first 12 weeks of life were as de- 
scribed by Stobo et al. (1966). The calves were weaned at 5 weeks of age and given hay and water $a d l i b$., together with a maximum daily allowance of concentrates of either $2.27 \mathrm{~kg}$ (treatments I and 2) or $0.45 \mathrm{~kg}$ (treatments 3 and 4 ). After I 2 weeks of age the calves were kept on slatted floors and given daily a constant amount of food, consisting of either 9 parts concentrates to I part hay (treatments I and 2) or I part concentrates to 3 parts hay (treatments 3 and 4 ). After a preliminary period of 7 days, digestibility and nitrogen-balance trials were made over a 7 -day period commencing on the 9 Ist day of life.

At the end of the first digestibility trial (period I), calves were given either concentrates (treatments $I$ and 3 ) or hay (treatments 2 and 4 ) together with water, the changeover being made gradually where necessary. After 7 days of ad lib. feeding with these diets, constant amounts of diet were given daily for a further 14 days, the last 7 of which constituted a second digestibility and N-balance trial (period 2).

\section{Digestibility trials}

Calves were kept in individual metabolism crates for a collection period lasting 7 days. Urine was collected into 3.5 l. bottles containing $25 \mathrm{ml}$ glacial acetic acid. The weight of urine was recorded twice daily and a $10 \%$ sample was stored at $4^{\circ}$. Faeces were collected in Polythene bags which were changed once or twice daily as necessary and, after thorough mixing, a 10\% sample of the faeces was stored at $-25^{\circ}$. At the end of the collection period the accumulated sample of faeces was thawed out and mixed, and a $50 \mathrm{~g}$ sample was acidified with $100 \mathrm{ml} 15 \%(\mathrm{v} / \mathrm{v})$ sulphuric acid for $\mathrm{N}$ determination. The remainder of the faeces was dried to constant weight at $100^{\circ}$ and the dry-matter content calculated.

\section{Sampling of blood and rumen contents}

Two days before the beginning of digestibility periods I and 2, i.e. at 89 and I ro days of age, samples of blood and rumen liquor were taken from each calf $\mathrm{I} 5 \mathrm{~min}$ before and at $\mathrm{I}, 2,3,4$ and $6 \mathrm{~h}$ after feeding. The blood sample was removed through a Polythene catheter, having an internal bore of $\mathrm{I} \mathrm{mm}$ and a wall $0.25 \mathrm{~mm}$ thick. The catheter was inserted into the jugular vein and stitched in place $2 \mathrm{~h}$ before the first sample was taken. To prevent coagulation of blood, the catheter was filled after each sampling with a dilute solution of heparin, consisting of $4 \mathrm{ml}$ heparin solution containing 5000 i.u. heparin/ml (Evans Medical Supplies Ltd, Liverpool) per 1. of $0.9 \%(\mathrm{w} / \mathrm{v})$ saline, and the end was sealed with a clip. Samples of $40 \mathrm{ml}$ of blood were removed by syringe, after constricting the jugular vein and allowing the first $2 \mathrm{ml}$ to go to waste. The contents of the syringe were transferred immediately to a tube containing four drops of the undiluted heparin solution and centrifuged at $2240 \mathrm{~g}$ for $20 \mathrm{~min}$. The plasma was drawn off and stored at $-25^{\circ}$.

Samples of rumen liquor, consisting of approximately $\mathrm{I} 0 \mathrm{ml}$, were collected by stomach tube at the stated time intervals for determination of $\mathrm{pH}$ and volatile fatty acid (VFA) concentrations. A further $150 \mathrm{ml}$ of rumen liquor were removed $3 \mathrm{~h}$ after feeding, for determination of bacterial population: a similar sample had been taken $2 \frac{1}{2} \mathrm{~h}$ after feeding when the calves were 56 days old. 


\section{Analytical methods}

The chemical composition of the dried samples of food and faeces and the $\mathrm{N}$ content of the acid faeces and urine were determined by the methods normally adopted: $\mathrm{N}$ was determined by the Kjeldahl method; crude fibre by digestion for $30 \mathrm{~min}$ in dilute sulphuric acid $(5 \%, \mathrm{w} / \mathrm{v})$ followed by dilute sodium hydroxide solution $(5 \%, \mathrm{w} / \mathrm{v})$ for a further $30 \mathrm{~min}$; ether extract by extraction in petroleum spirit (b.p. $40-60^{\circ}$ ) in a Soxhlet extraction apparatus, and ash by incineration in a muffle furnace at $560^{\circ}$. N-free extract was determined by difference.

Concentrations of blood plasma glucose (reducing sugar) were determined by the method of Nelson (1944) using the copper reagent of Somogyi (1952), blood plasma total VFA concentrations by the method of Scarisbrick (1952), and total VFA concentration in rumen liquor by the method described by Annison (1954). The proportions of individual VFA in the samples of rumen liquor were determined by paper chromatography, using the technique described by Reid \& Lederer (I95I) and Duncan $\&$ Porteus (I953).

\section{Rumen bacteria}

The viable counts of streptococci, lactobacilli and coliform organisms were determined by the dilution techniques described by Davey, Cheeseman \& Briggs (I960) on samples of rumen liquor taken at $2 \frac{1}{2} \mathrm{~h}$ ( 56 days) or $3 \mathrm{~h}$ ( 89 and I Io days) after feeding.

\section{Post-mortem examination}

Each calf was slaughtered at the end of the second digestibility trial and examined post mortem. The techniques adopted previously (Stobo et al. I966) were used to determine the weight of contents of the alimentary tract, volume displacement of the stomachs, weight of tissue forming the organs of the alimentary tract and rumen papillary development.

\section{RESULTS}

\section{Performance of the calves}

The results for the performance of the calves from 3 to 12 weeks of age and from I 5 to 17 weeks, together with information on food intake, are given in Table $I$ and Fig. I. As expected, calves given a maximum of $2 \cdot 27 \mathrm{~kg}$ concentrates daily gained weight significantly faster during the period $3^{-12}$ weeks of age than calves restricted to $0.45 \mathrm{~kg} /$ day of the same concentrate mixture. The majority of calves were eating $0.45 \mathrm{~kg}$ concentrates daily by the time they were weaned at 5 weeks; those restricted to this level of concentrates (treatments 3 and 4 ) consumed hay at a steadily increasing rate; those given a maximum allowance of $2 \cdot 27 \mathrm{~kg}$ concentrates/day (treatments $I$ and 2) reached this level at I I weeks of age, hay intake being correspondingly lower.

During the period ${ }^{1} 5^{-1} 7$ weeks, calves on treatments $I$ and 3 that received only concentrates, gained weight at a significantly faster rate than those on treatments 2 and 4 that were given hay as the sole diet. As shown in Table 1 , calves on treatment I gained weight significantly faster than those on treatment $3(0.7 \mathrm{I} \mathrm{kg} /$ day compared 
Vol. 20

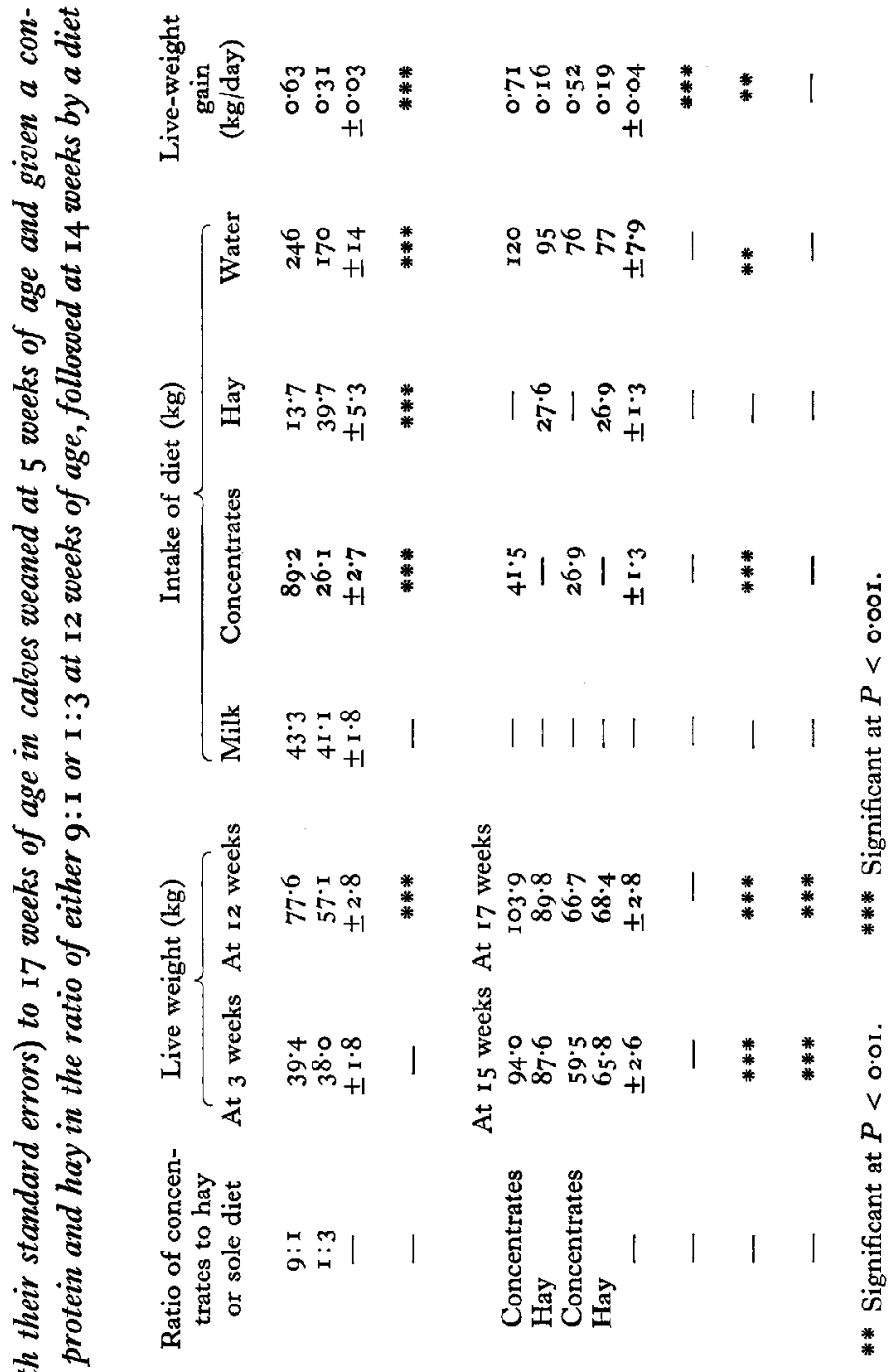

ํํㄹ

s.

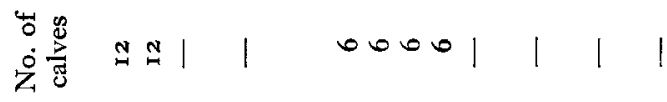

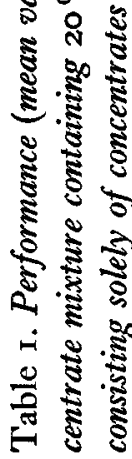

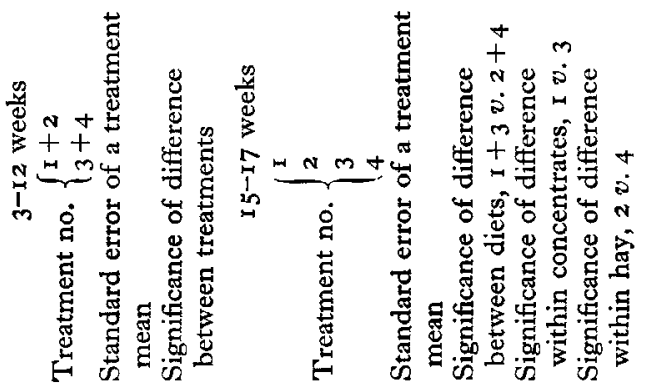


with $0.5^{2} \mathrm{~kg} /$ day respectively) but consumed a greater amount of concentrates. This may have been because those on treatment I were already accustomed to a highconcentrate diet, but since concentrate consumption/unit body-weight was almost identical with both treatments, it may be that the maximum intake of concentrates had been achieved by all calves. Since hay consumption/unit body-weight was lower in treatment 2 than in treatment 4 , it is possible that the reticulo-rumen, or the cavity enclosed by the abdominal walls, did not increase in capacity at a sufficiently rapid rate to accommodate the increased volume of contents when the diet was changed from one high in concentrates to one of hay only.

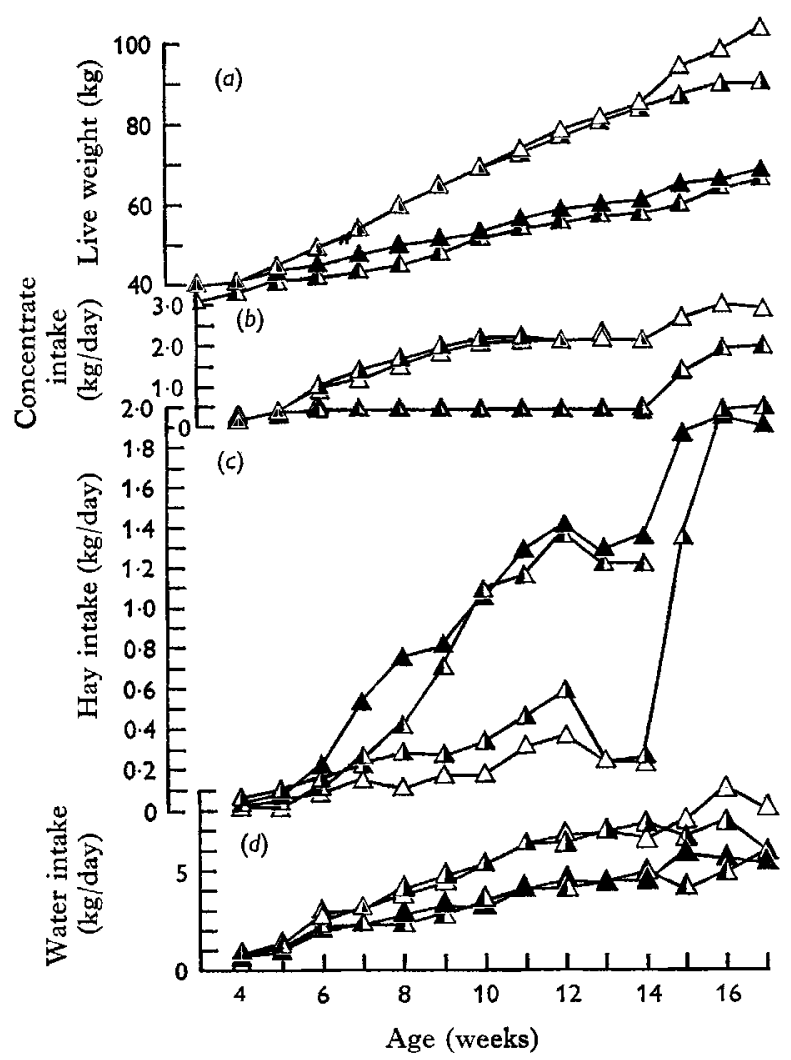

Fig. I. Mean live weight (a) and daily intake of concentrates $(b)$, hay $(c)$ and water $(d)$ of calves given diets consisting of concentrates and hay in different proportions. $\Delta-\Delta$, high-concentrate diet to 14 weeks followed by an all-concentrate diet; $\Delta-\Delta$, high-concentrate diet to I4 weeks followed by an all-hay diet; $\Delta-\Delta$, high-roughage diet to 14 weeks followed by an all-concentrate diet; $\wedge$ - , high-roughage diet to 14 weeks followed by an all-hay diet.

Table 2. Chemical composition (\%) of the foods used in the digestibility trials

\begin{tabular}{lcccccc}
\multicolumn{1}{c}{ Food } & $\begin{array}{c}\text { Dry } \\
\text { matter }\end{array}$ & $\begin{array}{c}\text { Crude } \\
\text { protein }\end{array}$ & $\begin{array}{c}\text { Crude } \\
\text { fibre }\end{array}$ & $\begin{array}{c}\text { Ether } \\
\text { extract }\end{array}$ & Ash & $\begin{array}{c}\text { Nitrogen-free } \\
\text { extract }\end{array}$ \\
Concentrates & $\mathbf{8 5} \cdot \mathbf{I}$ & $\mathbf{2 0 \cdot 1}$ & $\mathbf{3} \cdot 6$ & $\mathbf{1} \cdot \mathbf{9}$ & $4 \cdot 7$ & $54 \cdot 8$ \\
Hay & $84 \cdot 9$ & $7 \cdot 0$ & $\mathbf{2 4 . 3}$ & $\mathbf{1} \cdot \mathbf{2}$ & $5 \cdot 7$ & $46 \cdot 7$
\end{tabular}




\section{Digestibility}

The chemical composition of the diets used in the digestibility trials is given in Table 2 and the mean apparent digestibility coefficients are presented in Table 3 . The results show that when diets containing a high proportion of concentrates were given in period I the dry matter, crude protein, ether extract and $\mathrm{N}$-free extract fractions were digested more efficiently, and the crude fibre fraction digested less efficiently than when the diet consisted mainly of hay (differences significant at $P<0.00 \mathrm{I}$ ).

Table 3. Apparent digestibility coefficients (mean values with their standard errors) of the diet of calves given concentrates and hay in different proportions

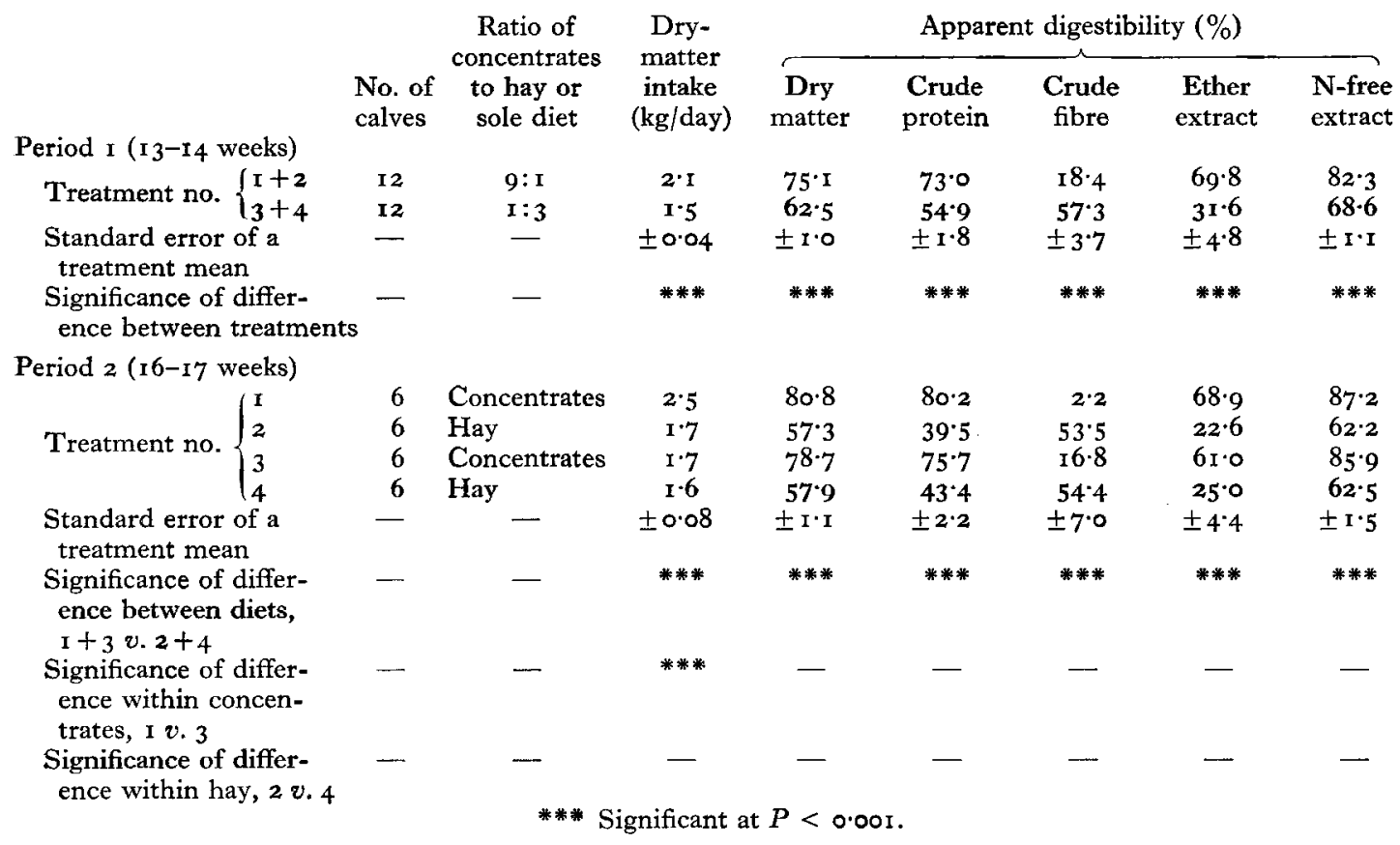

In period 2, when the diet consisted entirely of concentrates or of hay, the differences in apparent digestibility coefficients between the diets were even more pronounced. The apparent digestibility of dry matter, crude protein, ether extract and $\mathrm{N}$-free extract was slightly greater in treatment $I$ than in treatment 3 , although these differences were not significant. The low value of $75.7 \%$ for apparent digestibility of crude protein, found with treatment 3 in period 2, was the lowest value obtained by us for this high-protein concentrate; it was accompanied by the relatively high level of faecal $\mathrm{N}$ excretion of $0.86 \mathrm{~g} / \mathrm{100} \mathrm{g}$ dry-matter intake.

\section{Nitrogen balance}

Mean values for the $\mathrm{N}$-balance trials are presented in Table 4 . In period I calves given the high-concentrate diet (treatments $\mathrm{I}$ and 2) retained very much more $\mathrm{N}$ than those given the high-roughage diet (treatments 3 and 4). Those given the high- 


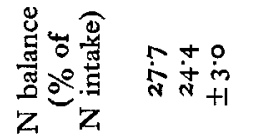

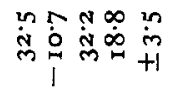

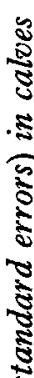

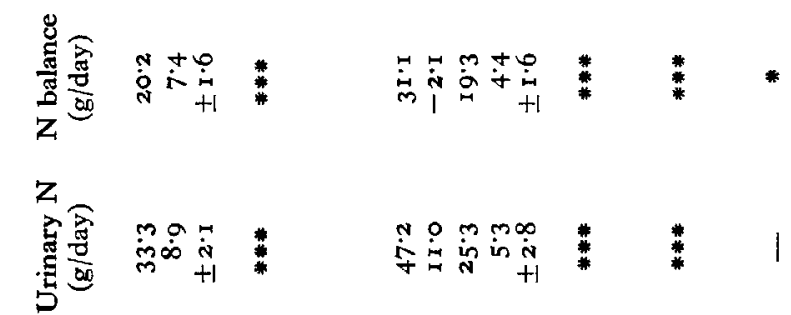

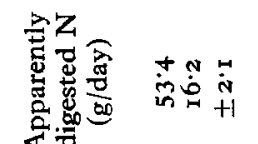

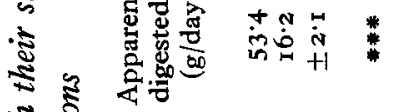

$\sin 200$

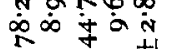

$\pi$

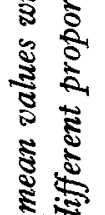

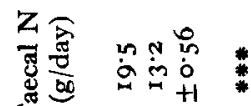

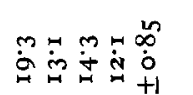

㲖趂

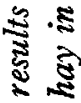

:

劳

要

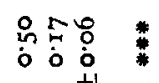

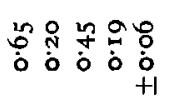

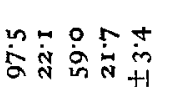

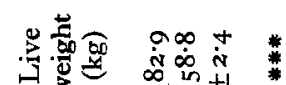

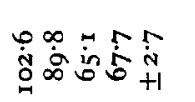

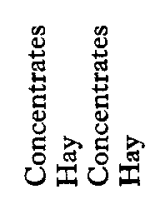

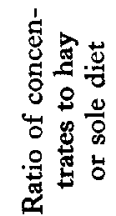

$\ddot{a} \ddot{m} \mid$

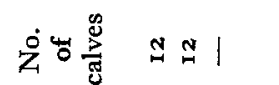

00001

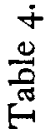

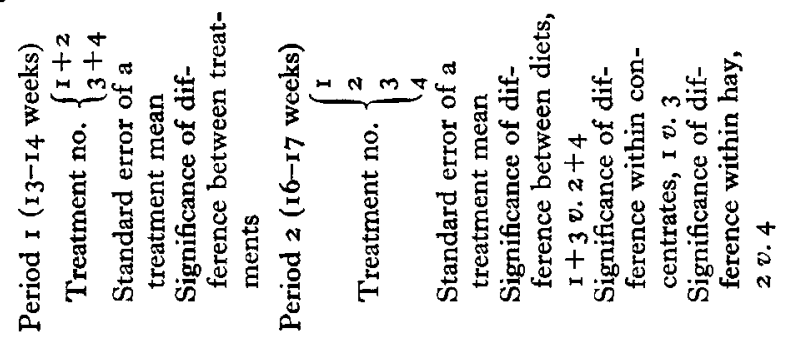


concentrate diet also excreted considerably more $\mathrm{N}$ in the urine and therefore made less efficient use of a greater intake of apparently digested $N$ (ADN) than those given the high-roughage diet. The amount of $\mathrm{N}$ retained was $4{ }^{\cdot} \mathrm{I} 3 \%$ of the mean live-weight gain, determined over the 14 -day period commencing 7 days before the beginning of the digestibility trial. Live-weight gain measured over the I4-day period was more closely related to $\mathrm{N}$ retention than was live-weight gain measured over a 7 -day period, since the longer period partly eliminated the effect of marked day-to-day fluctuations in live weight of calves while on digestibility trials; these fluctuations were thought to be caused by a combination of such factors as the strange environment of the digestibility crate, the effect of the harness and the frequent day-to-day irregularity in water consumption.

In period 2, the intake of $A D N$, excretion of urinary $\mathrm{N}$ and the amount of $\mathrm{N}$ retained were all significantly greater in calves given concentrates (treatments $\mathrm{I}$ and 3 ) than in those given hay (treatments 2 and 4 ). Four of the six calves on treatment 2 were in negative $\mathrm{N}$ balance, although only one calf lost weight, and it appears that the increase in weight of contents of the alimentary tract, that occurred when calves were changed from a high-concentrate to an all-hay diet, exceeded the loss in body tissue that occurred as the result of a lower level of nutrient intake. Calves on treatment $\mathrm{I}$ retained $3 \mathrm{r} \cdot \mathrm{I} \mathrm{g} \mathrm{N} /$ day, which was $6 \mathrm{I} \%$ greater than the amount retained by calves on treatment 3 , despite a higher level of urinary $\mathrm{N}$ excretion by the former group. Since the greater $\mathrm{N}$ balance was accompanied by a faster rate of growth, the amounts of $\mathrm{N}$ stored were 4.78 and $4.29 \mathrm{~g} / \mathrm{lo0} \mathrm{g}$ live-weight gain in treatments $\mathrm{I}$ and 3 respectively.

The efficiency of utilization of dietary $\mathrm{N}$ ( $\mathrm{N}$ balance expressed as a percentage of $\mathrm{N}$ intake) is also shown in Table 4. In period $\mathrm{I}$ the amount of $\mathrm{N}$ retained varied between $\mathrm{I} \cdot 4$ and $38.5 \%$ of the total $\mathrm{N}$ intake, but there was no significant difference between treatments, the mean value being $26.0 \%$. In period 2 , on the other hand, $32.4 \%$ of the $\mathrm{N}$ intake was retained in calves given the all-concentrate diet, with no difference between treatments I and 3 , compared with $18.8 \%$ on treatment 4 , in which calves were given the all-hay diet (differences significant at $P<0.05$ ). Since calves given hay after a high-concentrate rearing diet were in negative $\mathrm{N}$ balance, the efficiency of utilization of dietary $\mathrm{N}$ averaged $-10.7 \%$ in treatment 2 , which was significantly different $(P<0.001)$ from all the other mean values.

\section{Rumen $V F A$ and $p H$}

The mean total VFA concentration and $\mathrm{pH}$ of samples of rumen liquor taken ${ }_{1} 5$ min before feeding and I, 2, 3, 4 and $6 \mathrm{~h}$ after feeding are shown in Figs. 2 and 3 for periods I and 2 respectively. Although there was considerable within-treatment variation at any one sampling time, rumen total VFA concentration tended to increase with time after feeding to reach a peak at about $3 \mathrm{~h}$, accompanied by a steady decline in the $\mathrm{pH}$ of rumen contents. The mean values for total VFA concentration and rumen $\mathrm{pH}$ before, and $3 \mathrm{~h}$ after, feeding are presented in Table 5. At these times, although the concentration of total VFA in period I tended to be higher in calves given highconcentrate diets (treatments $I$ and 2) than in those given high-roughage diets (treat- 
ments 3 and 4 ), the differences were not significant. However, as can be seen from Fig. 2, the decline in concentration of total VFA that began $3 \mathrm{~h}$ after feeding was more rapid in calves given the high-roughage diet, so that an obvious difference was apparent at 4 and $6 \mathrm{~h}$ after feeding, mean values at these times being 8.69 and $7.7 \mathrm{I} \mathrm{m}$-equiv. $/ 100 \mathrm{ml}$ for high-concentrate diets, compared with 6.27 and $6.06 \mathrm{~m}$ equiv./100 $\mathrm{ml}$ for high-roughage diets. The decline in $\mathrm{pH}$ of rumen contents from before to $3 \mathrm{~h}$ after feeding was much greater with the high-concentrate than with the high-roughage diet.
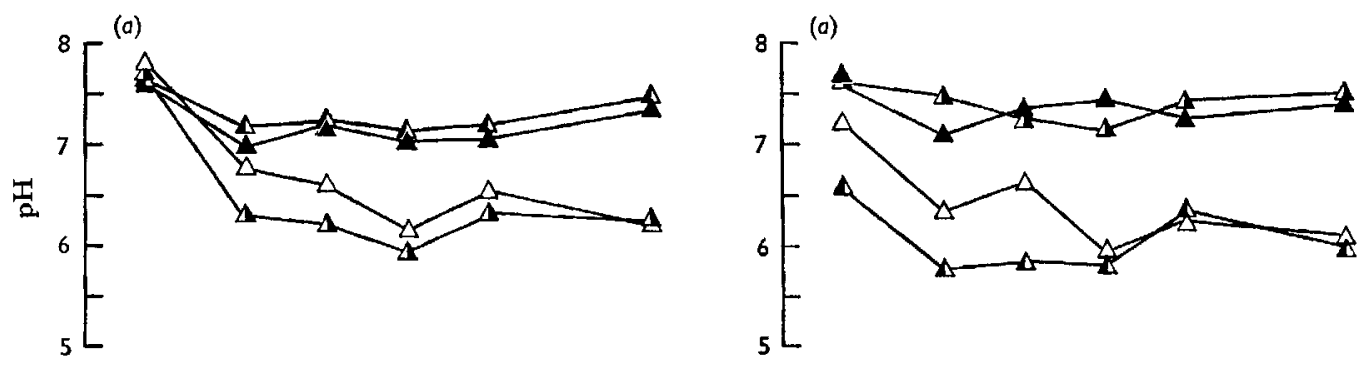

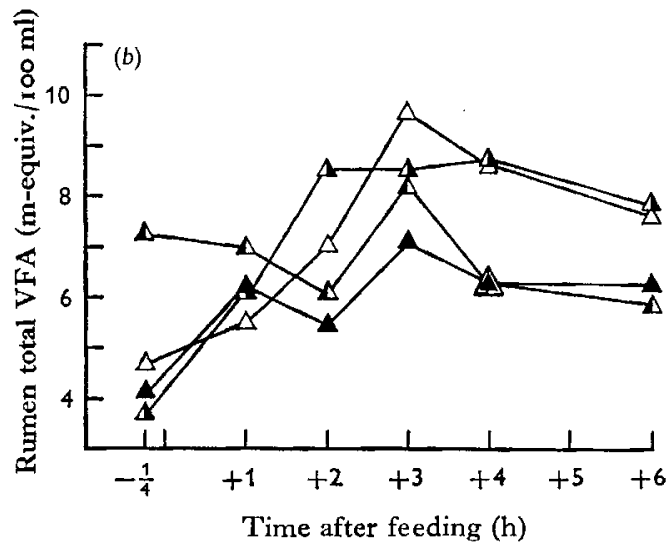

Fig. 2

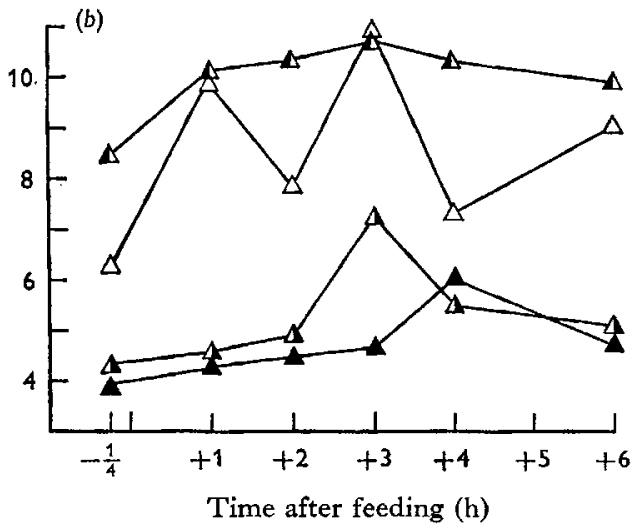

Fig. 3

Fig. 2. Period I. Mean pH (a) and total VFA concentration $(b)$ in the rumen liquor at intervals after feeding in 13 -week-old calves given a high-concentrate $(\Delta$ and $\Delta$ ) or a high-roughage $(\Delta$ and $\Delta$ ) diet.

Fig. 3. Period 2. Mean $\mathrm{pH}(a)$ and total VFA concentration $(b)$ in the rumen liquor at intervals after feeding in 16 -week-old calves given a diet consisting entirely of concentrates or of hay from I4 weeks of age. $\Delta-\Delta$, high-concentrate diet to 14 weeks followed by an all-concentrate diet; $\Delta-\Delta$, high-concentrate diet to 14 weeks followed by an all-hay diet; $\Delta-\Delta$, highroughage diet to $\mathrm{r}_{4}$ weeks followed by an all-concentrate diet; $\wedge-\Delta$, high-roughage diet to 4 weeks followed by an all-hay diet.

In period 2, the concentration of total VFA in the rumen was significantly greater in calves receiving the all-concentrate diet (treatments $I$ and 3 ) than in calves given only hay (treatments 2 and 4 ) both before and $3 \mathrm{~h}$ after feeding. At both of these times rumen $\mathrm{pH}$ was significantly higher in the hay-fed calves. Although differences within diets in period 2 did not reach significant levels, some were of sufficient magnitude to merit attention. For instance, the concentration of total VFA before feeding was 


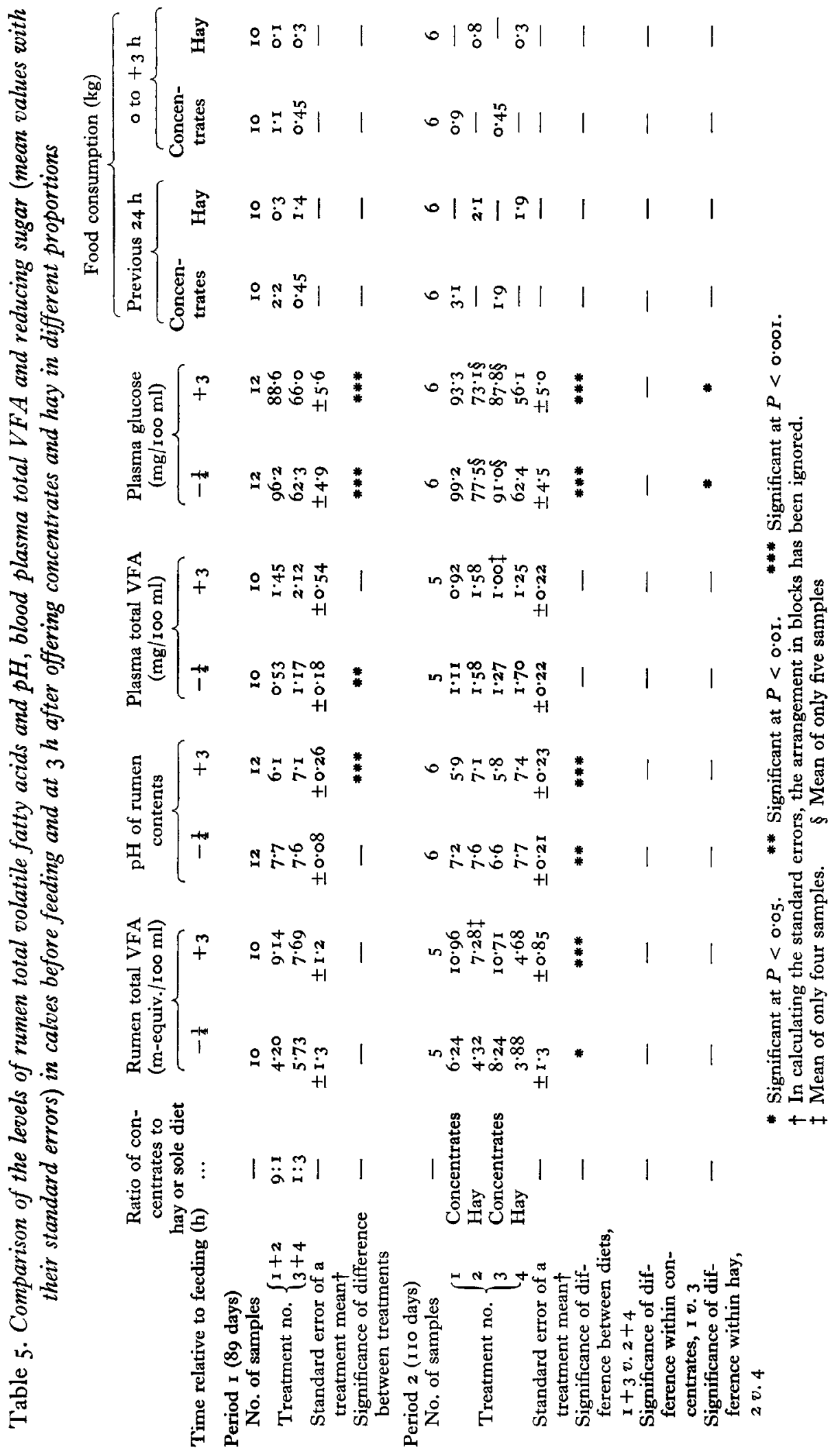




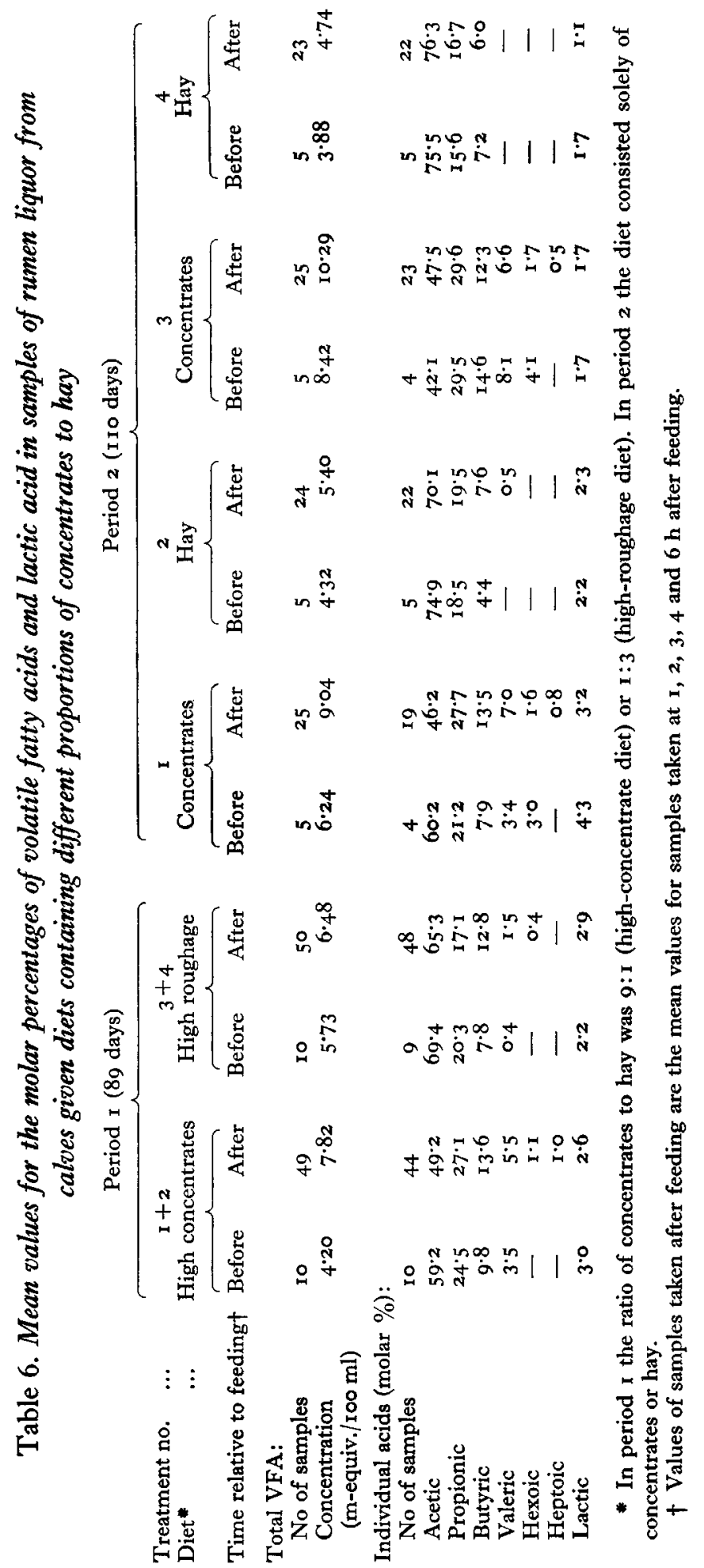


$35 \%$ higher in treatment 3 than in treatment $\mathrm{I}$, and this higher value was accompanied by a slightly lower $\mathrm{pH}$, whereas at $3 \mathrm{~h}$ after feeding the concentration of total VFA was $56 \%$ higher in treatment 2 than in treatment 4 , and again accompanied by a slightly lower $\mathrm{pH}$ value. The wide fluctuations in concentration of rumen total VFA in treatment $\mathrm{I}$ were found in three of the five calves used for the determination. Since no relationship could be found between VFA concentration in the rumen and the level of food intake, the results may reflect the difficulty of obtaining representative samples by stomach tube, especially from calves given an all-concentrate diet at a fairly high level of intake.

The proportions of individual VFA present in the rumen liquor, expressed as molar percentages, are shown in Table 6. It is clear that when the diet consisted of 9 parts concentrates to I part hay, there was proportionately less acetic acid and more propionic, butyric, valeric and higher acids in the rumen liquor than when the diet contained only I part concentrates to 3 parts hay. These differences became even more marked in period 2, for on all-concentrate diets the molar percentages were: acetic $47.5 \%$, propionic $28.4 \%$, butyric $12.8 \%$, valeric and higher acids $9.0 \%$, compared with corresponding values of $73.4,18 \cdot 0,6.8$ and $0.2 \%$ on all-hay diets. Lactic acid was present even on all-hay diets, but the proportion was slightly higher with calves reared on a high-concentrate diet. There was no marked carry-over effect of the rearing diet on the proportion of individual acids found in the rumen.

There was a distinct tendency for the molar percentage of propionic and butyric acids to increase at the expense of acetic acid, with increase in concentration of total VFA until the peak was reached, usually $3 \mathrm{~h}$ after feeding. As the total VFA concentration declined, the molar percentages of propionic and butyric acids also fell, suggesting that appreciable quantities of these acids are removed from the rumen, probably by absorption.

\section{Rumen bacteria}

The viable counts, expressed logarithmically, of streptococci, lactobacilli and coliform-type organisms are shown graphically in Fig. 4. It is clear that normal rumen bacteria had become well established even at 8 weeks of age. There was a significant reduction in the viable count between 13 and 16 weeks of age, following a change from a high-concentrate diet to one of all hay (treatment 2), streptococci falling from $10^{8.3}$ to $10^{6.2} / \mathrm{ml}$ (significant at $P<0.001$ ), lactobacilli from $10^{8.7}$ to $10^{6.3} / \mathrm{ml}$ (significant at $P<0.05$ ) and coliforms from $10^{5.7}$ to $10^{4.3} / \mathrm{ml}$ (significant at $P<0.0 \mathrm{r}$ ), but there was no other significant difference in viable count.

\section{Blood plasma VFA and reducing sugar}

The mean concentrations of total VFA and reducing sugars present in the plasma of blood drawn from the jugular vein at $15 \mathrm{~min}$ before and $\mathrm{I}, 2,3,4$ and $6 \mathrm{~h}$ after feeding are shown in Fig. 5 for period 1 and in Fig. 6 for period 2, and the mean initial and $3 \mathrm{~h}$ values are given in Table 5 .

Plasma VFA concentrations showed considerable variation within the range $0.24-4.80 \mathrm{mg} / 100 \mathrm{ml}$, but tended to be higher in hay-fed calves than in calves given diets containing mainly concentrates. In period $\mathrm{I}$ the mean plasma VFA concentra- 
tions rose to peak levels at the same time after feeding as those of rumen total VFA, but in period 2 there was a decline in plasma VFA concentration immediately after feeding, followed by a gradual rise in most instances. Whereas in period $\mathrm{I}$ the mean concentration was $I \cdot 14 \mathrm{mg} / 100 \mathrm{ml}$ plasma on high-concentrate diets and $\mathrm{I} \cdot 72 \mathrm{mg} /$ $100 \mathrm{ml}$ on high-hay diets, the concentrations had fallen to $\mathrm{I} \cdot 09$ and $\mathrm{I} \cdot 4 \mathrm{Img} / \mathrm{I} 00 \mathrm{ml}$,

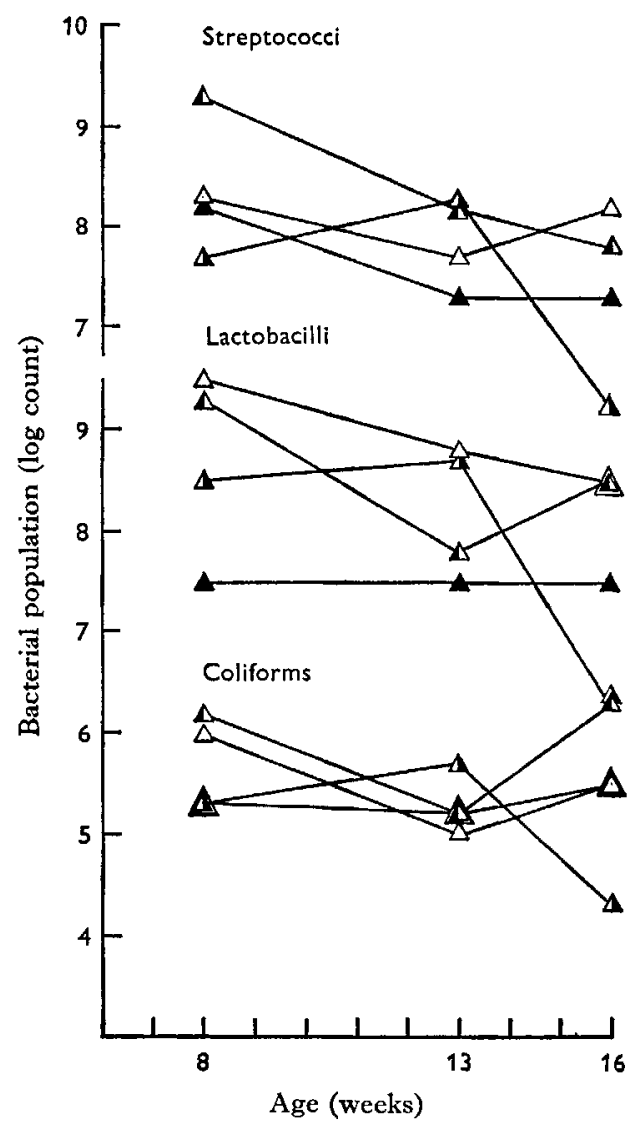

Fig. 4. Viable count of streptococci, lactobacilli and coliform-type organisms in the rumen liquor at $8, I_{3}$ and 16 weeks of age in calves given diets containing concentrates and hay in different proportions. $\Delta-\Delta$, high-concentrate diet to 14 weeks followed by an all-concentrate diet; $\Delta-\Delta$, high-concentrate diet to I 4 weeks followed by an all-hay diet; $\Delta-\Delta$, high-roughage diet to I 4 weeks followed by an all-concentrate diet; $\Delta-\Delta$, high-roughage diet to 14 weeks followed by an all-hay diet.

respectively, in period 2 . The biggest fall in plasma total VFA concentration occurred when, in treatment 3 , the high-hay diet was changed to all concentrates (from $\mathrm{I} \cdot 80$ to I. I I mg/I00 ml), but there was a rise from 1.12 to $1.52 \mathrm{mg} / 100 \mathrm{ml}$ in treatment 2 when an all-hay diet replaced one consisting mainly of concentrates. Changes in treatment $I$ were from $I \cdot I 7$ to $I .07 \mathrm{mg} / 100 \mathrm{ml}$ and in treatment 4 from 1.65 to I. $30 \mathrm{mg} / \mathrm{r} 00 \mathrm{ml}$.

The concentration of plasma glucose (reducing sugars) in period I was $44 \%$ higher 
in calves reared on the high-concentrate diet (treatments $I$ and 2) than in calves reared on the high-roughage diet (treatments 3 and 4 ), the overall mean values being $92.8 \mathrm{mg} / \mathrm{roO} \mathrm{ml}$ and $64.5 \mathrm{mg} / \mathrm{r} 00 \mathrm{ml}$ respectively. As shown in Table 5 , there were significant differences in glucose level between diets, both before and $3 \mathrm{~h}$ after feeding.

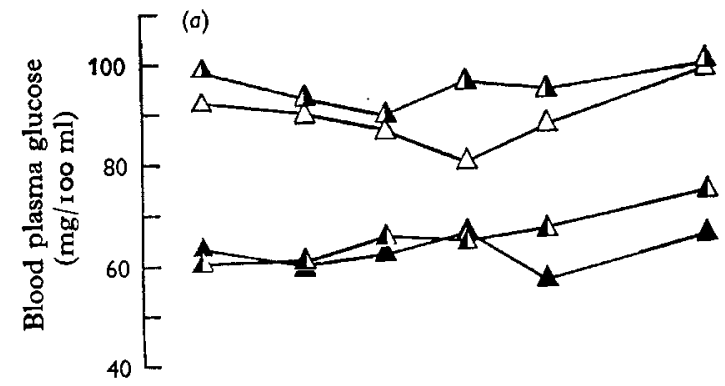

(a)

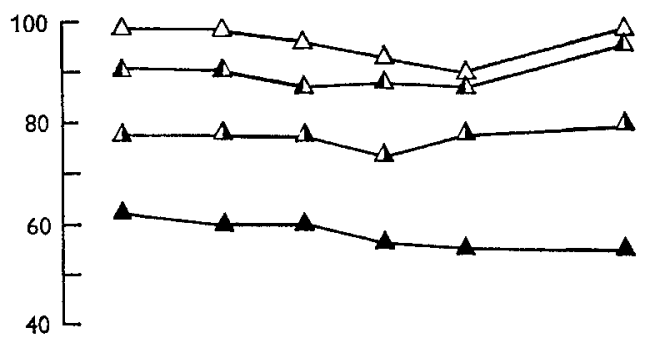

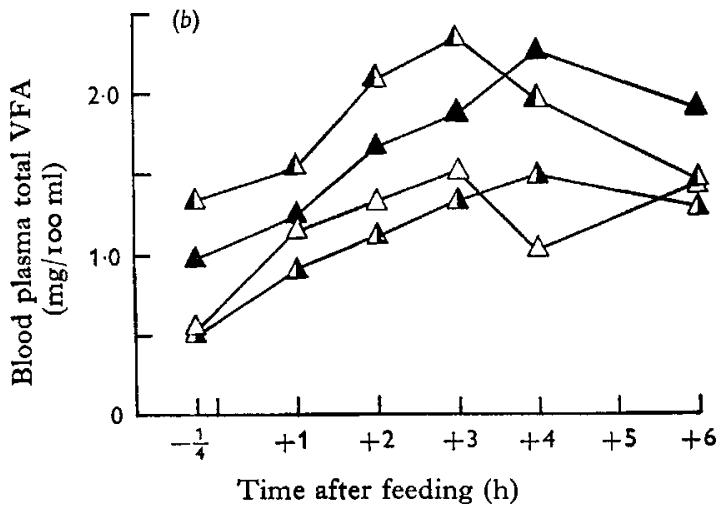

Fig. 5

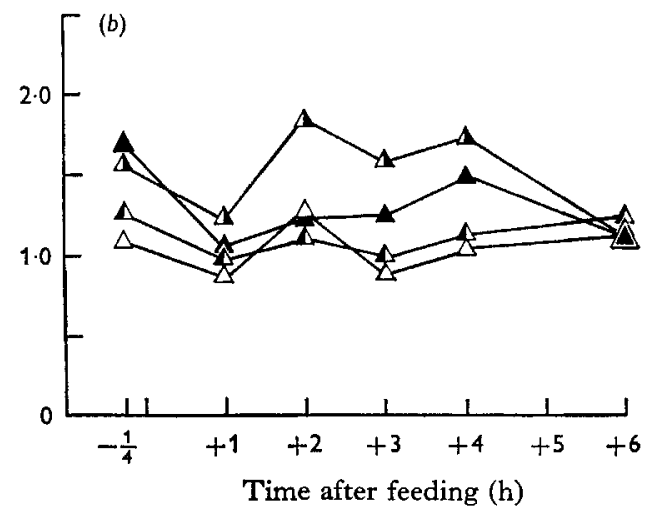

Fig. 6

Fig. 5. Period I. Mean concentrations of glucose $(a)$ and total VFA $(b)$ in blood plasma at intervals after feeding in 13 -week-old calves given a high-concentrate ( $\Delta$ and $\Delta$ ) or highroughage $(\Delta$ and $\Delta)$ diet.

Fig. 6. Period 2. Mean concentrations of glucose $(a)$ and total VFA $(b)$ in blood plasma at intervals after feeding in 16 -week-old calves given a diet consisting entirely of concentrates or of hay from 14 weeks of age. $\Delta-\Delta$, high-concentrate diet to 14 weeks followed by an allconcentrate diet; $\Delta-\Delta$, high-concentrate diet to 14 weeks followed by an all-hay diet; $\Delta-\Delta$, high-roughage diet to $\mathbf{I} 4$ weeks followed by an all-concentrate diet; $\Delta-\Delta$, highroughage diet to 14 weeks followed by an all-hay diet.

In period 2 , the overall mean concentrations of plasma glucose were $92.8 \mathrm{mg} / 100 \mathrm{ml}$ and $67.5 \mathrm{mg} / \mathrm{I00} \mathrm{ml}$ for all-concentrate (treatments $\mathrm{I}$ and 3 ) and all-hay (treatments 2 and 4) diets respectively. The increase in plasma glucose concentration in calves changed from a high-roughage to an all-concentrate diet (treatment 3 ) was greater than the decrease that occurred when calves were changed from a high-concentrate to an all-hay diet (treatment 2). The concentration of plasma glucose both before and $3 \mathrm{~h}$ after feeding was significantly higher $(P<0.05)$ in calves whose diet was changed 
from high-concentrate to all-hay (treatment 2) than in calves that received a high-hay diet throughout (treatment 4).

In both periods I and 2 plasma glucose concentration tended to decline, to reach minimum levels at $2-4 \mathrm{~h}$ after feeding. If this had corresponded with the rise in plasma VFA concentration it would have suggested an inverse relationship between glucose and VFA levels, but this relationship was not statistically significant, either in periods I and 2 separately, or in combination. However, it is of interest to speculate that had blood samples been taken from the portal vein, the concentrations of both glucose and VFA might have differed from those found in peripheral blood, and borne a more distinct inverse relationship to one another.

\section{Post-mortem examination}

Contents of the alimentary tract. The results given in Table 7 show that the weight of contents of the reticulo-rumen of calves that had received hay as the sole diet from I 4 to 17 weeks was approximately twice that found in calves given only concentrates.

Table 7. Mean values with their standard errors for the weight of contents of different parts of the alimentary tract, recorded on post-mortem examination at 17 weeks in calves given a diet consisting of concentrates and hay in the ratio of either $9: 1$ or $1: 3$ at 12 weeks of age, followed at $\mathrm{I}_{4}$ weeks by a diet consisting solely of concentrates or hay

\begin{tabular}{|c|c|c|c|c|c|c|}
\hline \multirow[b]{3}{*}{ Ratio of concentrates to } & \multicolumn{4}{|c|}{ Treatment no. } & \multirow{2}{*}{$\begin{array}{l}\text { error } \\
\text { of } \\
\text { means }\end{array}$} & \multirow{2}{*}{$\begin{array}{l}\text { between } \\
\text { two } \\
\text { means }\end{array}$} \\
\hline & $\mathbf{I}$ & 2 & 3 & 4 & & \\
\hline & 9:I & $9: I$ & $I: 3$ & $1: 3$ & - & - \\
\hline Diet after I4 weeks & Concentrates & Hay & Concentrates & Hay & - & - \\
\hline $\begin{array}{l}\text { No. of calves } \\
\text { Live weight at slaughter } \\
(\mathrm{kg})\end{array}$ & $\begin{array}{r}6 \\
105.8\end{array}$ & $\begin{array}{c}6 \\
89 \cdot 8\end{array}$ & $\begin{array}{c}6 \\
67 \cdot 9\end{array}$ & $\begin{array}{c}6 \\
69 \cdot 0\end{array}$ & $\frac{-}{ \pm 2 \cdot 7}$ & $\overline{8 \cdot 0}$ \\
\hline $\begin{array}{l}\text { Weight of contents of } \\
\text { reticulo-rumen }(\mathrm{kg})\end{array}$ & $7 \cdot 23$ & 14.29 & 6.06 & 14.50 & \pm 0.86 & $2 \cdot 60$ \\
\hline $\begin{array}{l}\text { Weight of contents of } \\
\text { omasum (g) }\end{array}$ & II9 & 759 & 95 & 647 & \pm 79 & 237 \\
\hline $\begin{array}{l}\text { Weight of contents of } \\
\text { abomasum (g) }\end{array}$ & 711 & 752 & 774 & 734 & $\pm \pi 13$ & $34^{\circ}$ \\
\hline $\begin{array}{l}\text { Weight of contents of } \\
\text { intestine }(\mathrm{kg}) \dagger\end{array}$ & 3.40 & $2 \cdot 87$ & $2 \cdot 37$ & $2 \cdot 68$ & \pm 0.19 & 0.57 \\
\hline $\begin{array}{l}\text { Weight of contents of } \\
\text { alimentary tract }(\mathrm{kg})\end{array}$ & II-46 & 18.67 & $9 \cdot 30$ & $18 \cdot 56$ & \pm 0.98 & 2.94 \\
\hline Empty body weight (kg) & $94 \cdot 3$ & $7 \mathrm{r} \cdot 2$ & $5^{8 \cdot 6}$ & $50 \cdot 4$ & $\pm 2 \cdot 6$ & 7.7 \\
\hline
\end{tabular}

+ Values calculated from an estimated $42.4 \%$ of total weight of intestine + contents (see p. 205 ).

The mean weight of contents of the reticulo-rumen in hay-fed calves was $14.4 \mathrm{~kg}$, equivalent to 16 and $21 \%$ of the live weight for treatments 2 and 4 respectively, and $6.7 \mathrm{~kg}$ in concentrate-fed animals, equivalent to 7 and $9 \%$ of live weight for treatments $\mathrm{I}$ and 3 respectively.

In the omasum, the mean weight of contents was much greater in the hay-fed calves 
than in those given the all-concentrate diet. There were no significant differences within hay or concentrates, but the weight of contents of the reticulo-rumen and omasum tended to be greater for calves on treatment $I$ than for those on treatment 3 . The weight of reticulo-rumen contents in the calves on these two treatments was not related to live weight or daily intake of concentrates.

There was a wide range in weight of contents of the abomasum, from $35^{2}$ to $1290 \mathrm{~g}$, but no difference between treatment means. The weight of contents of the intestine, assuming that the weight of contents was $42.4 \%$ of the weight of the intact intestinal tract, as suggested by Stobo et al. (1966), was significantly greater on treatment I than on either treatments 3 or 4 .

The total weight of contents of the alimentary tract was significantly greater in calves given the all-hay diet from 14 weeks, than in those given the all-concentrate diet, mainly because of the high proportion of total contents that was contained in the reticulo-rumen ( $77 \%$ for treatments 2 and 4 compared with $64 \%$ for treatments I and 3 ). The contents of the alimentary tract accounted for $26.9 \%$ of the live weight at slaughter in treatment 4 , but only $10.8 \%$ in treatment $\mathrm{I}$.

Table 8. Partial regression coefficients of the weight of contents of different parts of the alimentary tract on live weight at slaughter and daily concentrate consumption in the week before slaughter in calves given concentrates or hay as the sole diet

\begin{tabular}{|c|c|c|c|c|c|}
\hline & \multirow[b]{2}{*}{$\begin{array}{l}\text { General } \\
\text { mean } \\
\text { weight of } \\
\text { contents }\end{array}$} & \multicolumn{2}{|c|}{$\begin{array}{l}\text { Partial regression coefficients with } \\
\text { their standard errors } \dagger\end{array}$} & \multirow[b]{2}{*}{$\begin{array}{l}\text { Residual } \\
\text { standard } \\
\text { deviation }\end{array}$} & \multirow[b]{2}{*}{$\begin{array}{c}\text { Significance } \\
\text { of regression } \\
\text { equation }\end{array}$} \\
\hline & & $\begin{array}{l}\text { Live weight } \\
\text { (kg) }\end{array}$ & $\begin{array}{l}\text { Concentrate } \\
\text { consumption } \\
(\mathrm{kg} / \text { day })\end{array}$ & & \\
\hline General mean $\quad \ldots$ & - & $83 \cdot I$ & $1 \cdot 23$ & - & - \\
\hline Reticulo-rumen (kg) & 10.52 & $0.106 \pm 0.024 * * *$ & $-3.42 \pm 0.33 * * *$ & $\mathbf{I} \cdot 87$ & $* * *$ \\
\hline Omasum (g) & 405 & $7 \cdot 68 \pm 2 \cdot 4^{* *}$ & $-26_{3} \pm 33^{* * *}$ & 185 & $* * *$ \\
\hline Abomasum (g) & 743 & $0.378 \pm 3.5$ & $-13 \cdot 7 \pm 48$ & 272 & ns \\
\hline Intestine (kg) & $2 \cdot 83$ & $0.0179 \pm 0.0058 * *$ & $0.0120 \pm 0.078$ & 0.44 & $* *$ \\
\hline Total (g) & 1450 & $0.132 \pm 0.027^{* * *}$ & $-3.68 \pm 0.37$ ***** & $2 \cdot 10$ & $* * *$ \\
\hline
\end{tabular}

Empty body weight was significantly greater in calves given the high-concentrate diets to 14 weeks of age (treatments $I$ and 2) than in those given the high-roughage diets (treatments 3 and 4 ). At 14 weeks, empty body weight must have been similar for treatments $I$ and 2, and also for treatments 3 and 4 . The difference in empty body weight at 17 weeks, of $23 . \mathrm{I} \mathrm{kg}$ between treatments $\mathrm{I}$ and 2 and of $8.2 \mathrm{~kg}$ between treatments 3 and 4 , shows the marked effect of liberal concentrate feeding between $\mathrm{I}_{4}$ and 17 weeks of age.

Multiple covariance analyses of weight of contents of the reticulo-rumen, omasum, abomasum, intestine and total weight of contents were made for each organ separately using the variables: live weight at slaughter, daily concentrate consumption and daily hay consumption in the 7 -day period before slaughter. Hay consumption was not 
significant in its effect on weight of contents, and the partial regression coefficients were recalculated using live weight and concentrate consumption as the independent variables. The partial regression coefficients are presented in Table 8 .

Table 9. Comparison of the volume displacement of the intact organs and weight of tissue forming the organs of the alimentary tract (mean values with their standard errors) recorded on post-mortem examination at 17 weeks in calves given a diet consisting of concentrates and hay in the ratio of either 9:1 or $1: 3$ at 12 weeks of age, followed at I4 weeks by a diet consisting solely of concentrates or hay

\begin{tabular}{|c|c|c|c|c|c|c|}
\hline \multirow[b]{3}{*}{ Ratio of concentrates to } & \multicolumn{4}{|c|}{ Treatment no. } & \multirow{2}{*}{$\begin{array}{l}\text { error } \\
\text { of } \\
\text { means }\end{array}$} & \multirow{2}{*}{$\begin{array}{l}\text { difference } \\
\text { between } \\
\text { two means }\end{array}$} \\
\hline & $\mathbf{I}$ & 2 & 3 & 4 & & \\
\hline & $9: I$ & $9: I$ & $I: 3$ & $I: 3$ & - & - \\
\hline $\begin{array}{l}\text { Diet after I4 weeks } \\
\text { No. of calves } \\
\text { Empty body weight }(\mathrm{kg})\end{array}$ & $\begin{array}{l}\text { Concentrates } \\
6 \\
94 \cdot 3\end{array}$ & $\begin{array}{l}\text { Hay } \\
6 \\
7 I \cdot 2\end{array}$ & $\begin{array}{c}\text { Concentrates } \\
6 \\
5^{8.6}\end{array}$ & $\begin{array}{l}\text { Hay } \\
6 \\
50.4\end{array}$ & $\frac{-}{ \pm 2 \cdot 6}$ & $\frac{-}{7 \cdot 7}$ \\
\hline \multicolumn{7}{|c|}{ Volume displacement of intact organs: } \\
\hline $\begin{array}{l}\text { Reticulo-rumen (1.) } \\
\text { Omasum (1.) } \\
\text { Abomasum (1.) }\end{array}$ & $\begin{array}{r}27.8 \\
0.8 \\
3.4\end{array}$ & $\begin{array}{r}34 \cdot 2 \\
1 \cdot 9 \\
3 \cdot 7\end{array}$ & $\begin{array}{r}22 \cdot 7 \\
0.6 \\
3 \cdot 3\end{array}$ & $\begin{array}{r}37 \cdot 2 \\
1 \cdot 7 \\
3 \cdot 7\end{array}$ & $\begin{array}{l} \pm I \cdot 5 \\
\pm 0 \cdot I \\
\pm 0 \cdot 5\end{array}$ & $\begin{array}{l}4 \cdot 4 \\
0 \cdot 4 \\
1 \cdot 4\end{array}$ \\
\hline \multicolumn{7}{|c|}{ Weight of fresh organ tissues: } \\
\hline Reticulo-rumen (kg) & 3.07 & 2.3I & $2 \cdot 08$ & $I \cdot 84$ & $\pm 0 \cdot I I$ & 0.33 \\
\hline $\begin{array}{l}\text { Adjusted reticulo- } \\
\text { rumen tissue (kg)t }\end{array}$ & $2 \cdot 26$ & $2 \cdot 23$ & $\mathbf{2} \cdot 39$ & $2 \cdot 41$ & \pm 0.17 & 0.52 \\
\hline Omasum (g) & 608 & 830 & 390 & 722 & \pm 70 & 212 \\
\hline Abomasum (g) & 591 & 459 & 445 & $34 I$ & $\pm \mathbf{2 8}$ & 85 \\
\hline $\begin{array}{l}\text { Adjusted abomasum } \\
\text { tissue }(\mathrm{g}) \dagger\end{array}$ & 399 & $44^{\circ}$ & 520 & 477 & \pm 47 & I4I \\
\hline $\begin{array}{l}\text { Intestine (kg) } \ddagger \\
\text { Total (kg) }\end{array}$ & $\begin{array}{l}4 \cdot 62 \\
8 \cdot 90\end{array}$ & $\begin{array}{l}3.90 \\
7.50\end{array}$ & $\begin{array}{l}3 \cdot 23 \\
6 \cdot 14\end{array}$ & $\begin{array}{l}3 \cdot 64 \\
6 \cdot 54\end{array}$ & $\begin{array}{l} \pm 0.26 \\
\pm 0.27\end{array}$ & $\begin{array}{l}0.77 \\
0.83\end{array}$ \\
\hline \multicolumn{7}{|c|}{ Weight of oven-dried organ tissues: } \\
\hline Reticulo-rumen (g) & 571 & 312 & 305 & 231 & \pm 24 & $7 I$ \\
\hline $\begin{array}{l}\text { Adjusted reticulo- } \\
\text { rumen dried tissue }(\mathrm{g})\end{array}$ & $t^{439}$ & 299 & 356 & 325 & \pm 44 & 133 \\
\hline Omasum (g) & I I9 & 129 & 65 & IO2 & \pm 12 & 35 \\
\hline $\begin{array}{l}\text { Adjusted omasum } \\
\text { dried tissue }(\mathrm{g}) \dagger\end{array}$ & 33 & 120 & 98 & 163 & \pm 18 & 54 \\
\hline Abomasum (g) & 160 & 104 & 95 & 56 & \pm Io & $3 \mathrm{I}$ \\
\hline
\end{tabular}

Regression coefficient of weight of fresh tissue of reticulo-rumen on empty body weight $=0.032 \pm$ $0.008 * *$.

Regression coefficient of weight of fresh tissue of abomasum on empty body weight $=7 \cdot 49 \pm 2 \cdot 2 * *$.

Regression coefficient of weight of oven-dried tissue of reticulo-rumen on empty body weight $=$ $5 \cdot 15 \pm 2 \cdot 0^{*}$.

Regression coefficient of weight of oven-dried tissue of omasum on empty body weight $=3.33 \pm$ $0.82 * *$.

* Significant at $P<0.05$. * Significant at $P<0.01$.

+ Adjusted for differences between treatment groups in mean empty body weight.

I Values calculated from an estimated $57.6 \%$ of total weight of intestine + contents (see p. 205 ).

Volume displacement of the stomach compartments. The results given in Table 9 show that the volume displacement of the reticulo-rumen and omasum was significantly greater in calves given hay during the last 3 weeks of life than in calves given only 
concentrates. The difference between treatments $I$ and 3 in volume displacement of the reticulo-rumen was obviously related to the greater intake of concentrates by the former group ( $2.9 \mathrm{~kg} /$ day) than the latter group $(2 \cdot 0 \mathrm{~kg} /$ day), since there was a positive relationship between reticulo-rumen volume and total concentrate consumption during the period I $4-17$ weeks $(b=0.250 \pm 0.10$, significant at $P<0.05)$. The volume displacement of the abomasum did not differ between treatments.

Weight of tissue forming the organs of the alimentary tract. As shown in Table 9, the weight of fresh tissue forming the organs of the alimentary tract was greatest, except for the omasum, in treatment I. However, after treatment means had been adjusted for differences in empty body weight, by use of the regression coefficients given in Table 9, the differences were no longer significant.

The weight of tissue forming the omasum was greater in calves given hay from $I_{4}$ to 17 weeks of age than in calves given only concentrates during this period. However, since the weight of omasal tissue was significantly greater in treatment I than in treatment 3 , and in treatment 2 than in treatment 4 , it is clear that the weight of omasal tissue was related to empty body weight.

As expected, the weight of oven-dried tissues showed trends similar to those of the weight of fresh tissues, as given in Table 9.

Development of the rumen. The musculature of the rumen was well developed in all twenty-four calves. Although the muscular pillars appeared to be slightly thicker in the rumens of calves on treatment 4 than in those on treatment $I$, as judged from photographs at the end of the experiment, the greater development of papillas found in the areas adjacent to the pillars in treatment I may have obscured the extent of muscular development in the photographs. In consequence little importance is attached to this observation.

The extent of papillary development of the reticulo-rumen is presented photographically in Pls. I and 2, to show the anterior dorsal sac near the rumino-reticular fold and the ventral sac of the rumen. There was an obvious difference in the length and density of papillas in the different treatments. Dense clumps of papillas were found in calves on treatment $\mathrm{I}$, covering most of the internal surface of the rumen except for parts of the dorsal sac and the main parts of the muscular pillars. There was a tendency towards clumping together of papillas in three of the six calves on treatment 3 , although the development of the mucosa was not so marked as in treatment $r$. In treatments 2 and 4 there were no signs of clumping of papillas, although a larger area of the rumen was lined with papillas in the former of these two treatments.

Photographs of a section through the rumen wall in the region just caudal to the rumino-reticular fold are also shown in Pls. I and 2. The mean values for measurements made from these photographs for all twenty-four calves are shown in Table Io. The muscular wall was $1.8 \mathrm{~mm}$ thick in treatment 4 , compared with $2.6 \mathrm{~mm}$ in each of the other three treatments. The average length of papillas for each of the twentyfour calves ranged from $3.3 \mathrm{~mm}$ for a calf on treatment 4 to $10.5 \mathrm{~mm}$ for a calf on treatment $\mathrm{I}$, with mean values of 4.9 and $9 . \mathrm{I} \mathrm{mm}$ respectively for these two treatments. The mean length of papillas in treatment 3 , in which calves had been changed from a high-roughage diet to one of all concentrates, was $6.9 \mathrm{~mm}$, compared with $5.9 \mathrm{~mm}$ 
in treatment 2, in which the diet was changed from high-concentrates to all-hay. An estimate of the change in mean length of papilla following the change in diet is made in Table $\mathrm{I}$ by comparing the mean length of papilla found at $\mathrm{I} 7$ weeks in these calves after the change in diet with values found at I 2 weeks in calves given the corresponding high-concentrate or high-roughage rearing diets (Stobo et al. 1966). If the difference in length of papillas is assumed to represent the change in length in response to change in the diet at $\mathbf{I} 4$ weeks of age, there is a clear indication that papillary development progressed rapidly in the presence of concentrates (treatments $I$ and 3 ) and retrogressed almost as rapidly when concentrates were withdrawn from the ration and replaced by hay (treatment 2). Similar trends were shown in the weight of the $6 \mathrm{~cm}$ square section of rumen tissue, the differences in weight before and after change of diet being $+4 \cdot 4,-9^{\cdot} 6,+9^{\cdot} 4$ and $+r^{\circ} \circ g$ in treatments $1,2,3$ and 4 respectively.

Table Io. Mean values with their standard errors for the thickness of muscle and papillas in a $6 \mathrm{~cm}$ square section of the rumen wall from the region of the rumino-reticular fold, together with the weight of the section, recorded on post-mortem examination at 17 weeks in calves given concentrates and hay in the ratio of either $9: 1$ or $1: 3$ at 12 weeks of age, followed at $\mathrm{I}_{4}$ weeks by a diet consisting solely of concentrates or hay

\begin{tabular}{|c|c|c|c|c|c|c|}
\hline & \multicolumn{4}{|c|}{ Treatment no. } & \multirow{2}{*}{$\begin{array}{l}\text { Pooled } \\
\text { standard } \\
\text { error } \\
\text { of means }\end{array}$} & \multirow{2}{*}{$\begin{array}{l}5 \% \text { least } \\
\text { significant } \\
\text { difference } \\
\text { between } \\
\text { two means }\end{array}$} \\
\hline & $\mathbf{I}$ & 2 & 3 & 4 & & \\
\hline $\begin{array}{l}\text { Ratio of concentrates to } \\
\text { hay at } 12 \text { weeks }\end{array}$ & $9: I$ & $9: 1$ & $1: 3$ & $I: 3$ & 一 & - \\
\hline Diet after I 4 weeks & oncentrates & Hay & Concentrates & Hay & - & - \\
\hline No. of calves & 6 & 6 & 6 & 6 & - & 一 \\
\hline $\begin{array}{l}\text { Cross-section of rumen wall: } \\
\text { Thickness of muscle (mm) } \\
\text { Length of papillas (mm) } \\
\text { Total thickness of } \\
\text { muscle and papillas (mm) }\end{array}$ & $\begin{array}{r}2 \cdot 6 \\
9 \cdot 1 \\
11 \cdot 6\end{array}$ & $\begin{array}{l}2 \cdot 6 \\
5 \cdot 9 \\
8 \cdot 5\end{array}$ & $\begin{array}{l}2 \cdot 6 \\
6 \cdot 9 \\
9 \cdot 5\end{array}$ & $\begin{array}{l}I \cdot 8 \\
4 \cdot 9 \\
6 \cdot 7\end{array}$ & $\begin{array}{l} \pm 0.21 \\
\pm 0.33 \\
\pm 0.31\end{array}$ & $\begin{array}{l}0.6 \\
1.0 \\
0.9\end{array}$ \\
\hline $\begin{array}{l}\text { Weight of } 6 \times 6 \mathrm{~cm} \text { section } \\
\text { of rumen wall }(\mathrm{g})\end{array}$ & $43 \cdot 6$ & $29 \cdot 6$ & $32 \cdot 7$ & $24 \cdot 3$ & $\pm r \cdot 7$ & $5 \cdot 2$ \\
\hline
\end{tabular}

Table 1 I. Comparison of the length of rumen papillas in calves at 17 weeks, after changes in the diet at $\mathrm{I}_{4}$ weeks, with values obtained by Stobo et al. (1966) in calves given corresponding high-concentrate or high-roughage rearing diets to $\mathrm{I} 2$ weeks of age

\begin{tabular}{|c|c|c|c|c|}
\hline \multirow[b]{2}{*}{ Length of papillas (mm) } & \multicolumn{4}{|c|}{ Treatment no. } \\
\hline & $\mathbf{r}$ & 2 & 3 & 4 \\
\hline At 12 weeks (Stobo et al. 1966) & $7 \cdot 4$ & $7 \cdot 4$ & $4 \cdot 2$ & $4^{\prime 2}$ \\
\hline At 17 weeks (this experiment) & $9 \cdot I$ & 5.9 & $6 \cdot 9$ & 49 \\
\hline Difference & $+1 \cdot 7$ & $-\mathrm{I} \cdot 5$ & $+2 \cdot 7$ & +0.7 \\
\hline
\end{tabular}

These findings, supported by the observations on surface appearance, indicate that the rumen mucosa changed rapidly during the period ${ }^{14-17}$ weeks in response to different diets. 


\section{DISCUSSION}

The results of this experiment show clearly that high-concentrate diets given to calves weaned at 5 weeks of age promoted much more rapid growth than high-roughage diets, both in the rearing period to I4 weeks of age, and also in the succeeding period from 14 to 17 weeks, irrespective of previous diet. Measurements at $I 7$ weeks of age suggest that there was a rapid increase in the weight of contents of the alimentary tract after the change of diet at $\mathrm{I} 4$ weeks from high-concentrate to all-hay, and a corresponding decrease in contents when the diet was changed from one high in roughage to one of all-concentrates. However, the salient features of the experiment were the complete absence of the effect of previous diet on the ability of the calf to digest either concentrates or hay, and the rapidity with which it was possible to bring about extensive changes in papillary development, by an almost complete change of diet.

The performance of the calves from 3 to 12 weeks of age was almost the same as the results obtained previously (Stobo et al. 1966) with calves given the same levels of concentrate intake. Despite slight differences between the two experiments in the amounts of hay consumed, the assumption was made that factors, such as weight of contents of the different organs of the alimentary tract, volume displacement of the intact organs, weight of tissue forming the organs, and the extent of rumen development, were identical in calves at 12 weeks of age in the experiment now described to values obtained by Stobo et al. (1966) for calves given the same levels of concentrates. Thus, the mean values obtained in treatment 5 of the experiment of Stobo et al. (1966) were used in treatments $I$ and 2 of this experiment and those obtained in treatment $I$ of the previous experiment were used in treatments 3 and 4 of this experiment, to allow an estimate to be made of the effect of changing the diet of the calf at $\mathrm{I}_{4}$ weeks of age to one consisting solely of concentrates or hay.

From the values obtained at post-mortem, it is clear that considerable changes occurred in the weight of contents of the reticulo-rumen and omasum during the 3 -week period following the change in diet. Table 12 gives an estimate of the changes in weight of contents of the alimentary tract by comparing the weight of contents at slaughter with values calculated from measurements of live weight at I4 weeks and daily concentrate consumption in the I 4 th week using the partial regression coefficients determined previously (Stobo et al. I966). The weight of contents of the reticulorumen increased by $62 \%$ when hay was given in place of the high-concentrate diet (treatment 2) and fell by $43 \%$ when concentrates replaced the high-roughage diet (treatment 3). These compare with a $3 \mathrm{I} \%$ increase when hay followed a high-roughage diet (treatment 4) and a $21 \%$ reduction when concentrates followed a high-concentrate diet (treatment I).

The finding that the weight of contents of the reticulo-rumen was approximately twice as great with calves given hay as with calves given concentrates is in excellent agreement with the observations of Freer \& Campling (1963), who obtained a similar ratio with adult cows given diets consisting solely of hay or concentrates. This ratio between the two diets was almost the same at $6 \mathrm{~h}$ after feeding and at $24 \mathrm{~h}$ after the last meal. These workers found that concentrates were retained for a shorter period 
in the reticulo-rumen than hay, as shown previously by Paloheimo \& Mäkelä (1959), and no doubt this factor contributed greatly to the low weight of contents of the reticulo-rumen obtained with concentrate diets in our experiment.

Table 12. Mean weight of contents of various parts of the alimentary tract of calves given diets containing concentrates and hay in the ratio of either $9: 1$ or $1: 3$ from 12 to 14 weeks, calculated from regression equations obtained by Stobo et al. (1966), together with the weight of contents recorded when the calves, which were slaughtered at 17 weeks of age, had received either concentrates or hay during the preceding 3-week period

\begin{tabular}{|c|c|c|c|c|c|}
\hline \multirow{3}{*}{$\begin{array}{l}\text { Ratio of concentrates to hay } \\
12-14 \text { weeks }\end{array}$} & \multicolumn{4}{|c|}{ Treatment no. } & \multirow{3}{*}{$\begin{array}{l}\text { Regression equation used in } \\
\text { the calculations (from } \\
\text { Stobo et al. 1966) }\end{array}$} \\
\hline & $\mathbf{I}$ & 2 & 3 & 4 & \\
\hline & $9: \mathrm{I}$ & $9: 1$ & $1: 3$ & I : 3 & \\
\hline Diet after I 4 weeks & Concentrates & Hay & Concentrates & Hay & \\
\hline $\begin{array}{l}\text { Rumen contents }(\mathrm{kg}) \text { : } \\
\text { At I4 weeks (calculated) } \\
\text { At I7 weeks } \\
\text { Change from I } 4 \text { to I7 weeks }\end{array}$ & $\begin{array}{r}9 \cdot I I \\
7 \cdot 23 \\
-I \cdot 88\end{array}$ & $\begin{array}{r}8.80 \\
14.29 \\
+5.49\end{array}$ & $\begin{array}{r}10.66 \\
6.06 \\
-4.60\end{array}$ & $\begin{array}{r}11.11 \\
14.50 \\
+3.39\end{array}$ & $\begin{array}{c}y=9.20+0.194\left(x_{1}-69.0\right) \\
-3.89\left(x_{2}-\mathrm{I} \cdot 35\right)\end{array}$ \\
\hline $\begin{array}{l}\text { Omasum contents (g): } \\
\text { At I } 4 \text { weeks (calculated) } \\
\text { At I } 7 \text { weeks } \\
\text { Change from I } 4 \text { to I } 7 \text { weeks }\end{array}$ & $\begin{array}{r}251 \\
119 \\
-132\end{array}$ & $\begin{array}{r}234 \\
759 \\
+525\end{array}$ & $\begin{array}{r}166 \\
95 \\
-71\end{array}$ & $\begin{array}{r}198 \\
647 \\
+449\end{array}$ & $\begin{array}{l}y=242+10 \cdot 5\left(x_{1}-69 \cdot 0\right) \\
+327\left(x_{2}-1 \cdot 35\right) \\
-168\left(x^{2}-2 \cdot 20\right)\end{array}$ \\
\hline $\begin{array}{l}\text { Abomasum contents }(\mathrm{g}) \text { : } \\
\text { At } 14 \text { weeks (calculated) } \\
\text { At I } 7 \text { weeks } \\
\text { Change from I4 to } 17 \text { weeks }\end{array}$ & $\begin{array}{r}752 \\
711 \\
-4 I\end{array}$ & $\begin{array}{r}748 \\
752 \\
+4\end{array}$ & $\begin{array}{r}671 \\
774 \\
+103\end{array}$ & $\begin{array}{r}679 \\
734 \\
+55\end{array}$ & $\begin{array}{l}y=704+2 \cdot 70\left(x_{1}-69 \cdot 0\right) \\
+3 \cdot 61\left(x_{2}-1 \cdot 35\right)\end{array}$ \\
\hline $\begin{array}{l}\text { Intestine contents }(\mathrm{kg}) \text { : } \\
\text { At I } 4 \text { weeks (calculated) } \\
\text { At } 17 \text { weeks } \\
\text { Change from I } 4 \text { to } 17 \text { weeks }\end{array}$ & $\begin{array}{r}2.66 \\
3.40 \\
+0.74\end{array}$ & $\begin{array}{r}2 \cdot 65 \\
2 \cdot 87 \\
+0 \cdot 22\end{array}$ & $\begin{array}{r}2 \cdot 04 \\
2 \cdot 37 \\
+0.33\end{array}$ & $\begin{array}{r}2.06 \\
2.68 \\
+0.62\end{array}$ & $\begin{array}{l}y=2.35+0.0039\left(x_{1}-69.0\right) \\
\quad+0.288\left(x_{2}-1.35\right)\end{array}$ \\
\hline $\begin{array}{l}\text { Total contents of alimentary tra } \\
\text { At I } 4 \text { weeks (calculated) } \\
\text { At I } 7 \text { weeks } \\
\text { Change from } \text { I }_{4} \text { to } \text { I7 weeks }\end{array}$ & $\begin{array}{r}t(\mathrm{~kg}): \\
\quad 12 \cdot 85 \\
11 \cdot 46 \\
-1 \cdot 39\end{array}$ & $\begin{array}{r}12 \cdot 51 \\
18 \cdot 67 \\
+6 \cdot 16\end{array}$ & $\begin{array}{r}13 \cdot 60 \\
9 \cdot 30 \\
-4 \cdot 30\end{array}$ & $\begin{array}{r}14 \cdot 10 \\
18 \cdot 56 \\
+4 \cdot 46\end{array}$ & $\begin{array}{l}y=12 \cdot 49+0.212\left(x_{1}-69 \cdot 0\right) \\
-3.72\left(x_{2}-1 \cdot 35\right)\end{array}$ \\
\hline $\begin{array}{l}\text { Live-weight increase } 14-17 \\
\text { weeks }(\mathrm{kg})\end{array}$ & +20.2 & $+5 \cdot 8$ & $+9 \cdot 8$ & $+8 \cdot 2$ & \\
\hline $\begin{array}{l}\text { Live-weight increase } 14-17 \\
\text { weeks after allowing for } \\
\text { changes in weight of con- } \\
\text { tents of alimentary tract }(\mathrm{kg})\end{array}$ & $+21 \cdot 6$ & -0.4 & $+14 \cdot 1$ & +3.7 & \\
\hline
\end{tabular}

$y=$ weight of contents $; x_{1}=$ live weight at 14 weeks $(\mathrm{kg}) ; x_{2}=$ daily consumption of concentrates in I 4 th week (kg).

Trends in the weight of contents of the omasum were similar to those occurring in the reticulo-rumen, except that the increase in contents when calves were changed to an all-hay diet was greater than the decrease when concentrates were given as the sole diet. It would seem reasonable to argue that the retention time in the omasum was greater for hay than for concentrates, although there was no experimental evidence to support this. 
The volume displacement of each intact stomach compartment (1.) was found to be closely related to the weight of its contents. The regression coefficients were:

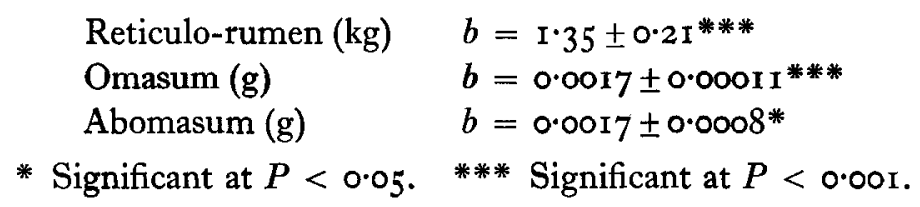

It is clear, therefore, that there is considerable elasticity in the walls of the reticulorumen and omasum, which are capable of stretching to accommodate the increase in bulk of contents when only hay is given, and of contracting to a much more compact size when only concentrates are given.

The finding that the weight of tissue forming the reticulo-rumen was related to empty body weight indicates that growth of rumen tissue occurs rapidly in the fastgrowing calf. However, the results for volume displacement and thickness of the rumen wall show that much of this increase in weight of tissue has come about as the result of papillary development rather than as growth of the muscular wall. This supports the observations in the lamb by Sinclair \& Künkel (1959) and confirms the conclusions of Stobo et al. (1966) that a well-developed rumen mucosa is associated with high rates of live-weight gain in the ruminant calf.

Harrison, Warner, Sander \& Loosli (I960) found that the rumen papillas had almost disappeared in calves changed from a diet of concentrates or of hay, at 16 weeks of age, to one of milk for a further 18 weeks, whereas retrogression of muscular tissue was much less noticeable. A remarkable retrogression of papillas was obvious in our experiment in treatment 2 , in which calves were changed from a high-concentrate to an all-hay diet, which they received for only 3 weeks. Even more marked was the rapid development of rumen papillas that took place in treatment 3 , after the change from a high-hay to an all-concentrate diet.

It has already been established that butyrate and, to a lesser extent, propionate stimulate papillary development (Sander, Warner, Harrison \& Loosli, 1959; Tamate McGilliard, Jacobson \& Getty, 1962). In treatment 2 there was a decrease in the mean concentration of total VFA, a reduction in the proportion of propionic, butyric and higher acids and a rise in $\mathrm{pH}$ of the rumen liquor, whereas in treatment 3 the opposite occurred, after the change in diet.

Interpretation of the observations on papillary development is difficult in the absence of information on the daily amount of VFA produced in the rumen. No attempt was made to estimate the daily production of VFA in this experiment, since the rate of their absorption from the rumen was not known. However, from the values given in Table 6 , it seems probable that the production of propionic, butyric and higher acids was greater in calves given all-concentrate diets than in those given all-hay.

The possibility that the $\mathrm{pH}$ of the rumen liquor also played an important part in promoting papillary development must not be discounted. Danielli, Hitchcock, Marshall \& Phillipson (1945) found that absorption of VFA occurred at a faster rate when the rumen contents were acid, the higher homologues being absorbed faster at $\mathrm{pH} 5 \cdot 8$ than at $\mathrm{pH} 7 \cdot 5$. Thus, in treatment 3 it would seem that conditions were ideal for the 
rapid development of rumen papillas. On the other hand, the marked retrogression of papillas in treatment 2 may have been associated with a reduction in the rate of absorption, particularly of butyrate and propionate, due to the lower concentration of these acids and to the higher $\mathrm{pH}$ in the rumen. The stretching of the walls of the rumen, that occurred when hay was given as the sole diet, would reduce the height and density of the papillas and, since comparison with the results obtained in a previous experiment (Stobo et al. 1966) suggested that the total weight of rumen tissue continued to increase at a slow rate, there would appear to have been little or no reduction in the total amount of rumen mucosa.

Most of the digestibility coefficients obtained at 13 weeks of age were very similar to values obtained when diets of hay and concentrates in different proportions were given to mature cows (Balch, 1957), 2-year-old heifers (Balch et al. 1960), and 12-weekold calves (Conrad \& Hibbs, 1953), but the digestibility of crude fibre was considerably below the values obtained by these workers, especially when diets containing large amounts of concentrates were given, being $57 \%$ when the proportion of hay to concentrates was $3: \mathrm{I}$ and only $\mathrm{I} 8 \%$ when it was $\mathrm{I}: 9$. This suggests that there was a shortage of cellulose-splitting organisms in the rumen, or that the more readily available carbohydrates present, particularly in the high-concentrate diet, were attacked in preference to the fibrous fraction, as observed by Arias, Burroughs, Gerlaugh \& Bethke (195I). The development of large numbers of cellulose-splitting organisms was found by Lengemann \& Allen (1959) to reach adult levels at 9 weeks of age in calves given a maximum of $1.4 \mathrm{~kg}$ of concentrates/day. However, Bryant, Small, Bouma \& Robinson (1958) and Conrad, Hibbs \& Frank (1958) found that very few protozoa were present at 4 months of age in calves given high-concentrate diets if they were not given rumen inoculations from older animals. Conrad, Hibbs, Pounden \& Sutton (1950) had previously shown that protozoa and some cellulosesplitting bacteria disappeared from the rumen when the proportion of concentrates in the diet was increased. These authors found that, when hay was given later, the digestibility of dry matter was reduced from the previous level of $67 \%$ to $58 \%$ and of cellulose from $65 \%$ to $54 \%$ if these organisms did not reappear in the rumen.

Except for the crude fibre fraction, the apparent digestibility coefficients of mixed diets given in period $\mathrm{I}$ did not differ from the weighted mean of the digestibility coefficients of concentrates and hay, when given separately in period 2. That the digestibility of crude fibre in period I was greater than in period 2 by $14 \%$ on the high-hay diet and by $4 \%$ on the high-concentrate diet suggests that there may be an optimum ratio of concentrates to hay for the development of cellulose-splitting organisms, possibly in combination with an optimum rate of passage of digesta through the alimentary tract.

In view of the difficulty of obtaining representative samples by stomach tube from non-fistulated animals, and because of the possibility that such samples might be contaminated by saliva, with a resultant increase in rumen $\mathrm{pH}$ and reduction in the concentration of VFA, the observations on rumen VFA concentration must be treated with caution. However, the observed rise in concentration of total VFA, reaching a peak at approximately $3-4 \mathrm{~h}$ after feeding, is in accordance with the findings of Balch 
\& Rowland (1957) and Stewart, Stewart \& Schultz (1958) in adult cattle and of Gray, Jones \& Pilgrim (1960) in sheep.

The concentration of total VFA in the rumen has been found to reach adult levels at about 6 weeks of age in calves given a high-roughage diet (Conrad et al. 1958) and at 7-8 weeks of age in calves given a high-concentrate diet (Lengemann \& Allen, 1955; McCarthy \& Kesler, 1956). In our experiment when the calves were 8 weeks of age the mean concentrations of VFA in rumen samples, taken $2 \frac{1}{2} \mathrm{~h}$ after food was given, were 8.9 and $7.9 \mathrm{~m}$-equiv./100 $\mathrm{ml}$ for high-hay and high-concentrate diets respectively and were in close agreement with values obtained $3 \mathrm{~h}$ after feeding by these other workers. Although the concentration of VFA did not alter markedly between 8 and 14 weeks of age, the increase in volume of rumen contents, which is almost certain to have occurred, must indicate an increase in total production of VFA between these ages.

At about 14 weeks of age, the proportion of individual VFA in the rumen of calves given high-roughage diets was shown by Conrad et al. (1958) to be acetic $72 \%$, propionic $19 \%$ and butyric $9 \%$; whereas with calves given high-concentrate diets Lengemann \& Allen ( 1955 ) found values of acetic $59 \%$, propionic $21 \%$, butyric $14 \%$ and others $6 \%$. Despite fairly close agreement between these results and those of our experiment, the values give no indication of the amounts of each individual acid produced, because the rate at which the acids disappear from the rumen are probably different for each acid. Moreover, changes in volume of rumen contents are likely to occur with time after feeding, particularly on high-roughage diets, and probably confound the results. However, by calculating the concentration of each acid present at different times, it was found that in calves on all-concentrate diets propionic acid accounted for up to $40 \%$ and butyric acid up to $30 \%$ of the increase in VFA that occurred between feeding and $3 \mathrm{~h}$ after feeding, whereas on all-hay diets acetic acid accounted for $100 \%$ of the increase in VFA during the first hour after feeding, followed by an increase in propionic acid to $30 \%$ and of butyric acid to $15 \%$ of the total increase in VFA at $3 \mathrm{~h}$ after feeding.

It is well established that VFA are absorbed from the rumen, but not all the VFA appears in peripheral blood. Kiddle, Marshall \& Phillipson (195I) first showed that the concentration of butyrate in portal blood was less than that expected in relation to its absorption from the rumen. Later work by Pennington (1952) established that rumen epithelial cells metabolized butyrate and produced an increase in the concentration of ketone bodies in the portal blood, as shown by Annison, Hill \& Lewis (1957). Reid (I950) had previously shown that propionate was removed by the liver with the production of glucose.

It thus becomes apparent that, whereas the calf given a diet consisting mainly of roughage utilizes considerable amounts of acetate as a source of energy to the tissues, the calf given a high-concentrate diet relies more on glucose as its energy source. This is in agreement with the findings of this experiment, that the VFA concentration in peripheral blood was higher, and blood sugar concentration was lower, in hay-fed than in concentrate-fed calves.

The concentrations of plasma reducing sugars in calves given the high-hay diet are in agreement with values reported in 3-month-old calves reared on the high-roughage 
system (Hibbs, Conrad \& Pounden, I952; Hibbs, Conrad, Pounden \& Frank, I956). The concentrations found in calves given high-concentrate diets were up to $20 \mathrm{mg} /$ $100 \mathrm{ml}$ higher than values reported by Preston $\&$ Ndumbe (196I) in calves between Io and 16 weeks of age, given all-concentrate diets at a daily rate of $8 \%$ of the metabolic body size $\left(\mathrm{kg}^{0.74}\right)$. In period 2 of our experiment, concentrates were given at $10 \%$ (treatment I) and $9.5 \%$ (treatment 3 ) of metabolic body size $\left(\mathrm{kg}^{0.73}\right)$.

The extent to which the higher plasma glucose concentrations, obtained on concentrate diets as opposed to hay, may be attributed to the glucogenic effect of propionate, or to glucose formed by hydrolysis of starch in the intestine, is uncertain, since little is known of the extent to which starch can bypass the rumen. Preston \& Ndumbe ( 1961 ) also observed a temporary depression in blood glucose of concentratefed calves $3 \mathrm{~h}$ after feeding, but to a minimum level of about $60 \mathrm{mg} / \mathrm{I00} \mathrm{ml}$. These workers postulated that the decline in blood glucose after feeding was the result of additional requirements for glucose in metabolizing VFA mixtures low in propionic acid, a condition they assumed to exist. The results of our experiment have shown that, in fact, the molar percentage of propionic acid in the rumen contents of concentrate-fed calves is very high (mean value $\mathbf{2 8 . 4} \%$ of total VFA). Moreover, the proportion of propionic acid actually increased at the time when plasma glucose levels were at their minimum. However, it may be that the increase in concentration of butyrate, which occurred $3 \mathrm{~h}$ after feeding, and which would be expected to have a higher specific absorption rate than propionate at a $\mathrm{pH} 5 \cdot 8-6 \cdot 2$ had a depressing effect on plasma glucose, since the available evidence suggests that butyrate, as well as acetate, is not glucogenic and may even depress blood glucose levels (Storry \& Rook, I96r; Blaxter, 1962).

The rise in plasma glucose concentration that occurred $3 \mathrm{~h}$ after feeding was accompanied, in most instances, by a decrease in the concentration of butyrate. However, it may be that the hydrolysis of dietary starch to glucose in the intestine had an effect on blood glucose levels, which were shown by Preston \& Ndumbe (1961) to rise gradually to maximum levels 8-I2 $\mathrm{h}$ after food was eaten.

In conclusion, the findings of this experiment have demonstrated the marked ability of the ruminant calf to adapt itself rapidly to severe changes in its diet, enabling it to digest a virtually new diet as efficiently as can a similar animal given the diet for a considerable period of time. It was apparent that the metabolic processes that occurred within the growing calf differed between high-concentrate and high-roughage diets, and that changes in the diet resulted not only in a transition in the metabolic processes, but also in a rapid transformation in the anatomical development of the reticulo-rumen and omasum.

We are indebted to Dr L. A. Davey (present address Pfizers, Sandwich, Kent) for the VFA analyses of rumen and blood samples and for the bacteriological studies, to Mr N. G. J. Gruber for the photographic work and to Mrs L. M. H. Belcher and Mr A. F. Hamnett for the chemical analyses. We also thank Mr A. Wilson and Mr A. K. Oliver for the care of the experimental animals. One of us (I.J.F.S.) was in receipt of a Wellcome Research Fellowship of the Animal Health Trust. 
British Fournal of Nutrition, Vol. 20, No. 2

Plate I
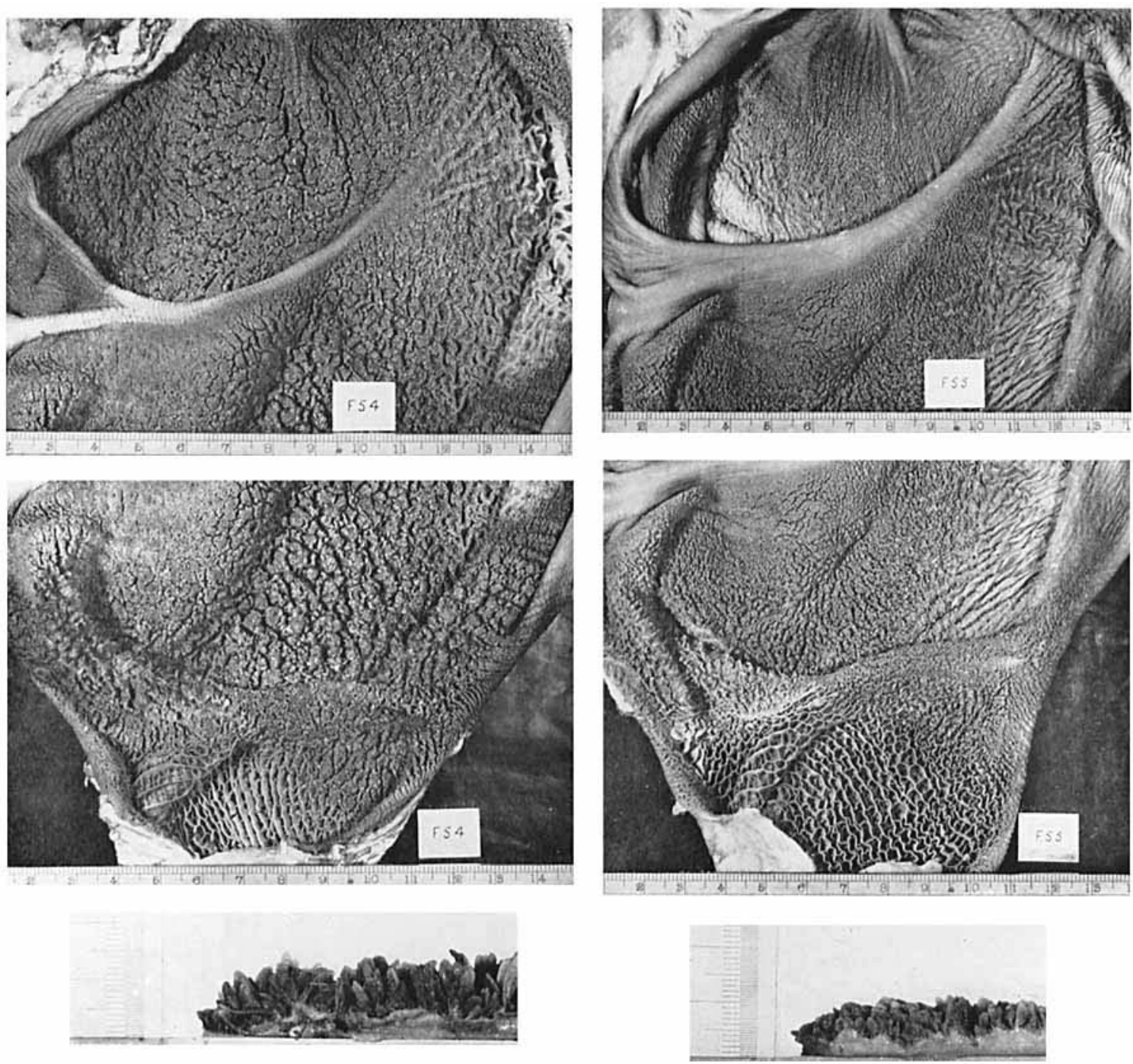

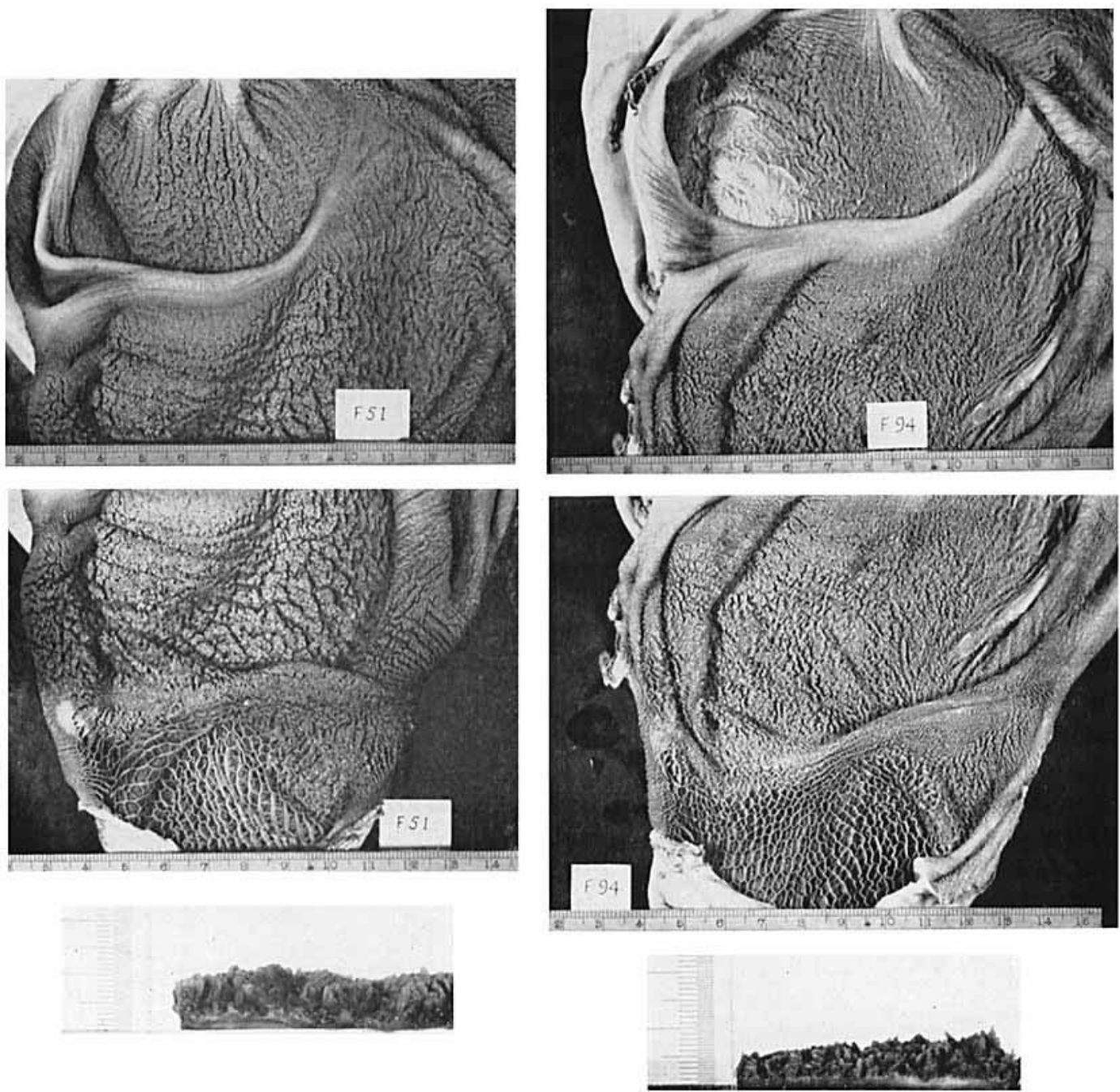

I. J. F. STOBO, J. H. B. ROY AND HELEN J. GASTON (2) 


\section{REFERENCES}

Annison, E. F. (1954). Biochem. F. 57, 400 .

Annison, E. F., Hill, K. J. \& Lewis, D. (I957). Biochem. F. 66, 592.

Arias, C., Burroughs, W., Gerlaugh, P. \& Bethke, R. M. (1951). F. Anim. Sci. ro, 683.

Balch, C. C. (1957). Br. F. Nutr. Ix, 213.

Balch, C. C., Campling, R. C., Johnson, V. W. \& Roy, J. (1960). Br. F. Nutr. 14, 379.

Balch, D. A. \& Rowland, S. J. (1957). Br. F. Nutr. 11, 288.

Blaxter, K. L. (1962). The Energy Metabolism of Ruminants. London: Hutchinson.

Bryant, M. P., Small, N., Bouma, C. \& Robinson, I. (1958). F. Dairy Sci. 4I, 1747.

Conrad, H. R. \& Hibbs, J. W. (1953). F. Dairy Sci. 36, 1326.

Conrad, H. R., Hibbs, J. W. \& Frank, N. (1958). F. Dairy Sci. 4I, r 248.

Conrad, H. R., Hibbs, J. W., Pounden, W. D. \& Sutton, T. S. (I950). F. Dairy Sci. 33, 378.

Crichton, J. A. \& Aitken, J. N. (1954). Proc. Nutr. Soc. 13, I0.

Danielli, J. F., Hitchcock, M. W. S., Marshall, R. A. \& Phillipson, A. T. (1945). F. exp. Biol. $22,75$.

Davey, L. A., Cheeseman, G. C. \& Briggs, C. A. E. (1960). F. agric. Sci., Camb., 55, 155.

Duncan, R. E. B. \& Porteus, J. W. (1953). Analyst, 78, 641.

Filmer, J. F. (1952). Rep. Dep. Agric. N.Z. p. 8.

Freer, M. \& Campling, R. C. (1963). Br. F. Nutr. 17, 79.

Gray, F. V., Jones, G. B. \& Pilgrim, A. F. (1960). Aust. F. agric. Res. 11, 383.

Hansson, A., Brännäng, E. \& Claesson, O. (1953). Acta agric. scand. 3, 61.

Harrison, H. N., Warner, R. G., Sander, E. G. \& Loosli, J. K. (1960). F. Dairy Sci. 43, 1301.

Hibbs, J. W., Conrad, H. R. \& Pounden, W. D. (1952). F. Anim. Sci. 11, 764.

Hibbs, J. W., Conrad, H. R., Pounden, W. D. \& Frank, N. (1956). F. Dairy Sci. 39, I71.

Kiddle, P., Marshall, R. A. \& Phillipson, A. T. (I95 I). F. Physiol., Lond., I13, 207.

Lengemann, F. W. \& Allen, N. N. (1955). F. Dairy Sci. 38,651.

Lengemann, F. W. \& Allen, N. N. (1959). F. Dairy Sci. 42, I 17 I.

McCarthy, R. D. \& Kesler, E. M. (1956). F. Dairy Sci. 39, 1 280.

Nelson, N. (1944). F. biol. Chem. 153, 375 .

Paloheimo, L. \& Mäkelä, A. (1959). Suom. maatal. Seur. Fulk. 94, 15.

Pennington, R. J. (I952). Biochem. $\mathscr{~ F . ~ 5 I , ~} 25$ r.

Preston, T. R. \& Ndumbe, R. D. (I96r). Br. F. Nutr. 15, 28I.

Reid, J. T., Loosli, J. K., Turk, K. L., Asdell, S. A. \& Smith, S. E. (1957). F. Dairy Sci. 40, 610.

Reid, R. L. (1950). Nature, Lond., 165, 448.

Reid, R. L. \& Lederer, M. (1951). Biochem. $7.50,60$.

Sander, E. G., Warner, R. G., Harrison, H. N. \& Loosli, J. K. (1959). F. Dairy Sci. 42, I60o.

Scarisbrick, R. (1952). Biochem. F. 50, xxxiv.

Sinclair, J. H. \& Künkel, H. O. (1959). Proc. Soc. exp. Biol. Med. 102, 57.

Somogyi, M. (1952). F. biol. Chem. r95, 19.

Stewart, W. E., Stewart, D. G. \& Schultz, L. H. (1958). F. Anim. Sci. 17, 723.

Stobo, I. J. F., Roy, J. H. B. \& Gaston, H. J. (1966). Br. Y. Nutr. 20, 171.

Storry, J. E. \& Rook, J. A. F. (196I). Biochim. biophys. Acta, 48, 610.

Tamate, H., McGilliard, A. D., Jacobson, N. L. \& Getty, R. (1962). F. Dairy Sci. 45, 408.

\section{EXPLANATION OF PLATES}

Rumen development in the ventral sac (top) and the anterior dorsal sac in the region of the ruminoreticular fold (middle) in 17 -week-old calves given a diet consisting solely of concentrates or hay after a rearing diet high in concentrates or in roughage (scale graduated to 0.1 in). The cross-section photograph (bottom) shows muscle thickness and papilla length in the anterior dorsal sac just caudal to the rumino-reticular fold (scale graduated to $0.5 \mathrm{~mm}$ ).

\section{Plate I}

F 54. Rumen development in a calf given concentrates as the sole diet after a rearing diet high in concentrates (treatment 1 ).

F 55. Rumen development in a calf given hay as the sole diet after a rearing diet high in concentrates (treatment 2).

Plate 2

F 5 I. Rumen development in a calf given concentrates as the sole diet after a rearing diet high in roughage (treatment 3 ).

F 94. Rumen development in a calf given hay as the sole diet after a rearing diet high in roughage (treatment 4). 